\title{
Recent advances in amyotrophic lateral sclerosis research: perspectives for personalized clinical application
}

\author{
Chen Benkler • Daniel Offen • Eldad Melamed • \\ Lana Kupershmidt • Tamar Amit • Silvia Mandel • \\ Moussa B. H. Youdim • Orly Weinreb
}

Received: 28 March 2010 / Accepted: 19 May 2010 /Published online: 29 June 2010

(C) European Association for Predictive, Preventive and Personalised Medicine 2010

\begin{abstract}
Treatment of amyotrophic lateral sclerosis (ALS) has been fueled, in part, by frustration over the shortcomings of the symptomatic drugs available, since these do not impede the progression of this disease. Currently, over 150 different potential therapeutic agents or strategies have been tested in preclinical models of ALS. Unfortunately, therapeutic modifiers of murine ALS have failed to be successfully translated into strategies for patients, probably because of differences in pharmacokinetics of the therapeutic agents, route of delivery, inefficiency of the agents to affect the distinct pathologies of the disease or inherent limitations of the available animal models. Given the multiplicity of the pathological mechanisms implicated in ALS, new therapies should consider the simultaneous manipulation of multiple targets. Additionally, a better management of ALS therapy should include understanding the interactions between potential risk factors, biomarkers and heterogeneous clinical features of the patients, aiming to manage their adverse events or personalize the safety profile of these agents. This review will discuss novel pharmacological approaches concerning adjusted therapy for ALS patients: iron-binding brain permeable multimodal compounds, genetic manipulation and cell-based treatment.
\end{abstract}

C. Benkler $\cdot$ D. Offen $\cdot$ E. Melamed

Felsenstein Medical Research Center, Tel Aviv University,

Tel-Aviv, Israel

L. Kupershmidt • T. Amit - S. Mandel • M. B. H. Youdim •

O. Weinreb $(\bowtie)$

Eve Topf Centers of Excellence for Neurodegenerative Diseases

Research and Department of Pharmacology,

Rappaport Family Research Institute,

Technion-Faculty of Medicine,

P.O.B. 9649, Haifa 31096, Israel

e-mail: worly@tx.technion.ac.il
Keywords Amyotrophic lateral sclerosis .

Iron chelating-multifunctional drugs · Stem cells .

Genetic manipulation · Neurotrophic factors .

Personalized medicine

\section{Introduction}

Amyotrophic lateral sclerosis (ALS), commonly referred as 'Lou Gehrig's disease' is a relentlessly progressive, neurological disorder with an estimated uniform prevalence of 4-6 cases per 100,000 in Western countries, where it is $50-100$ times higher than elsewhere in the world [1,2]. The onset of ALS is most common in midlife between 45-65 years of age, with a typical disease course of one to 5 years [2]. The progressive stage of this disease is characterized by specific degeneration of both upper and lower motor neurons in the brain, brainstem and spinal cord, resulting in paralysis due to muscle weakness and atrophy [3]. In a small percentage of cases, dementia is observed [4]. The majority of patients die within 3-5 years of symptom onset because of respiratory failure. Only $10 \%$ of all ALS cases are characterized as genetic familial ALS (fALS), whereas the vast majority is of unknown etiology and classed as sporadic ALS (sALS) [5, 6]. Both forms of ALS are clinically and pathologically similar, suggesting a possible common pathogenesis and final pathway of neurodegeneration [7] though sALS generally develops later than fALS [8].

However, the underlying cause of ALS remains elusive, as well as the development of the chain of events leading to this disease, contributing to the lack of effective therapy. Treatment of ALS has been fueled in part by frustration over the shortcomings of the symptomatic drugs available, since they are incapable of slowing down disease progression 
and neuronal degeneration. Currently, over 150 different potential therapeutic agents or strategies have been tested in transgenic ALS mice according to published reports [9]. This list involves 108 pharmacotherapies, 14 gene or antisense therapies, 9 cell transplantations, 3 immunizations and 7 dietary or lifestyle regimens. The pharmacotherapy spectrum encompasses antioxidants, anti-excitotoxins, antiaggregation compounds, anti-apoptotics, anti-inflammatories and neurotrophic agents. However, most of the candidates have been reported to have limited therapeutic benefits and only modest effects on survival of ALS patients. In addition, therapeutic modifiers of murine ALS have failed to be successfully translated into strategies for patients, probably because differences in pharmacokinetics of the therapeutic agents, route of delivery, inefficiency of the agents to affect the distinct pathologies of the disease or inherent limitations of the available animal models [10, 11]. For example, antioxidant treatments such as vitamin E, N-acetylcysteine, and L-methionine demonstrated to delay the disease onset and progression in an ALS animal model [12], show a lack of clinical efficacy in randomized controlled trials in 830 ALS patients [13]. Similarly, systemic administration of the anti-apoptotic compound, minocycline, a second-generation tetracycline antibiotic, that can delay the symptom onset in ALS animal model [14], has been reported to fail in a multicenter, phase III, randomized, controlled trial in more than 400 ALS patients [15]. Regrettably, riluzole, an antiglutamatergic agent, demonstrated to inhibit the presynaptic release of glutamate and the only drug for the treatment of ALS approved by the US Food and Drug Administration (FDA), is reported to have limited therapeutic benefits and only modest effects on survival of ALS patients [16].

To improve ALS disease management, therapy should include understanding of the interactions between potential risk factors, biomarkers and heterogeneous clinical features of the patients, with the aim of improving management of their adverse events or personalizing the safety profile of these agents. This knowledge may offer a superior distinction of the pathological profiles among individuals or groups of ALS patients and in turn lead to new-focused therapeutic clinical trials.

The clinical aspects and advanced therapies in personalized treatment of ALS patients are beyond the scope of this review and thoroughly discussed by Nefussy and Drory in the current issue [17]. The current review will discuss novel therapeutic approaches employed in preclinical models of ALS, including iron-binding brain permeable compounds possessing multimodal neuroprotective activities and genetic and cell-based therapies. These therapeutic approaches take into account the various challenging features of this disease and the interplay of genetic and environmental risk factors, to provide superior efficacy in translation from preclinical studies to the clinic.

\section{Multifunctional-iron chelating therapeutic strategies in ALS}

Current therapeutic strategies suggest that drugs acting at a single target may be insufficient for the treatment of multifactorial neurodegenerative diseases, such as Parkinson's disease (PD), Alzheimer's disease (AD) and ALS, all characterized by the coexistence of multiple pathologies. The molecular pathogenesis of ALS is poorly understood, contributing to the lack of effective system-based therapies to treat this disease. Investigations have inferred that ALS is a multifactorial and multisystemic disease, that arises from combination of several mechanisms which act through concurring damage inside motor neurons and their neighboring nonmotor cells. These include genetic factors; oxidative stress (OS) damage; mitochondrial malfunction; protein misfolding and aggregation; defective axonal transport; neurofilament aggregation; increased glutamate excitotoxicity; neuroinflammation; deficits in neurotrophic factors and dysfunction of cell signaling pathways $[2,5,18]$.

The effect of OS within neurons has been studied mainly in the G93A-superoxide dismutase (SOD)1 transgenic mouse model- related fALS (which develops symptoms and pathology similar to those of ALS patients); however, the roles of OS in sALS remain obscure. Recently, a role of iron in OS-induced motor neuron damage has been suggested. It is well established that ionic iron, participates in the Fenton chemistry and reacts with hydrogen peroxide to produce reactive oxygen species (ROS), displays elevated iron levels in the central nervous system (CNS) of both sporadic and familial forms have been reported [19, 20]. Indeed, a recent clinical report described a patient, who was diagnosed with neurodegeneration and brain iron accumulation, but had clinical criteria for frontotemporal dementia and picture of ALS [4]. Recently, a defect in the Hfe gene, which has been previously associated with iron overload diseases, hemochromatosis and Alzheimer's disease (AD), is currently associated with ALS [21]. The protein normally made by the Hfe gene is thougt to limit the uptake of iron by cells, to protect against OS and possibly to dampen inflammatory reactions. An increased incidence of the Hfe mutation has been reported in ALS patients [22]. The presence of this mutation was shown to disrupt expression of tubulin and actin at the protein levels potentially consistent with the disruption of axonal transport seen in ALS and associated with a decrease in SOD1 expression [22]. In support for the involvement of iron in ALS pathology, the iron-responsive protein transferrin, was localized in Bunina bodies of spinal cord neurons from ALS patients [23, 24], suggesting its involvement in the formation of these inclusions.

In accordance with the human studies, in the G93A-SOD1 transgenic mouse model, the expression of ferritin was 
induced at late stages of the disease, indicating high iron concentrations [15]. Interestingly, in transgenic mice expressing the wild type SOD1 or SOD1-active mutant enzyme, G93A-SOD1, the expression of transferrin receptor (TfR) and iron regulatory proteins 1 (IRP1), a positive transcriptional regulator of TfR [25], were positively modulated in response to increased SOD1 mutation [23]. Jeong and collaborators [26] have recently described dysregulation of iron homeostasis mechanism in the CNS in the G37RSOD1 transgenic mice model of ALS, suggesting that iron chelating therapy might be useful for the treatment of ALS. In support, iron-binding porphyrin (a catalytic antioxidant) treatment has extended survival and increased neuronal survival in the spinal cord in G93A-SOD1 mice [27].

Noticeably, drug therapy of neurodegenerative diseases with multifunctional compounds embracing diverse biological properties with single bioavailability and pharmacokinetic metabolism, will have a pronounced advantage over individual-target drug or cocktail of drugs. Based on this reasoning, Youdim and collaborators [28, 29] have designed and synthesized several chimeric compounds, by amalgamating the neuroprotective propargyl moiety of the anti-Parkinson's drug/ irreversible selective monoamine oxidase (MAO)-B inhibitor, rasagiline [N-propargyl-1R $(+)$-aminoindan], Azilect (Teva Pharmaceutical Netanya Industries, Ltd. Israel) into the antioxidant-iron chelating skeleton of the 8-hydroxyquinoline derivative of VK-28, to produce several multiomodal compounds for combating neurodegenerative diseases, such as ALS.

In searching for the superlative neuroprotective agents in a series of multifunctional iron chelators, the compound M30 (5-[N-methyl-N-propargylaminomethyl]-8-hydroxyquinoline) (Fig. 1) was found to be a most potent iron chelator, nontoxic, brain permeable, displaying highly effective inhibition of MAO-A and -B activities in vitro and in vivo and iron-induced membrane lipid peroxidation [2832]. Additionally, M30 was found to invoke a wide range of pharmacological activities, including a neurorescue response, a protective potency against OS insults and regulatory action on neuronal differentiation and neurite outgrowth in various neuronal cell lines [33-36]. In in vivo studies, M30 possesses a significant neuroprotective as well as neurorescue activity against N-methyl-4-phenyl-1,2,3,6tetrahydropyridine (MPTP) neurotoxicity in mice [30, 31]. In addition, both M30 and VK28 were found to prevent the loss of mice tyrosine hydroxylase $(\mathrm{TH})$ positive neurons, induced by post-intra-nigral injection of lactacystin, significantly improve behavioral performances and attenuate inhibition of ubiquitin-proteasome activity, iron increase and microglial activation in the ipsilateral substantia nigra (SN) [37].

Given the diversity of pathological mechanisms implicated in ALS, which suggested that multiple pathways may

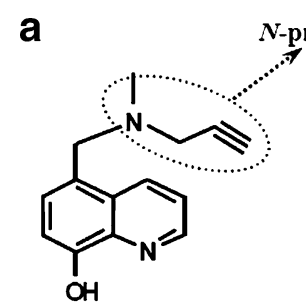

M30

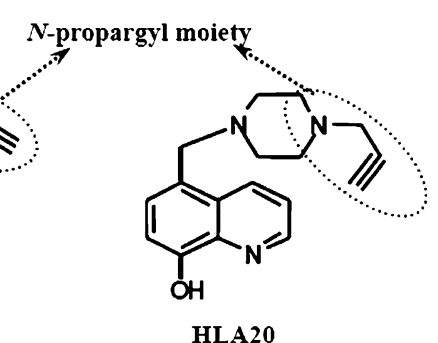

b

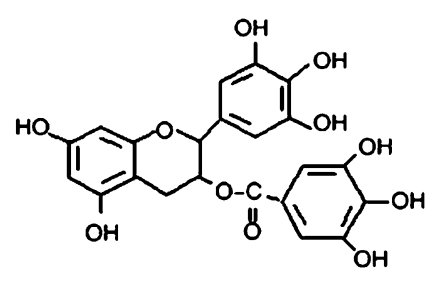

(-)-epigallocatechin-3-gallate (EGCG)
Fig. 1 Chemical structure of the novel brain permeable, multifunctional iron chelating compounds and the natural iron chelator, EGCG. a M30 (5-[N-methyl-N-propargylaminomethyl]-8-hydroxyquinoline) and HLA20 (5-[4-propargylpiperazin-1-ylmethyl]-8-hydroxyquinoline), restrained the propargyl moiety. b The major polyphenolic compound of green tea, (-)-epigallocatechin-3-gallate, EGCG

contribute to this disease [38], new ALS therapies may consider a simultaneous manipulation of multiple targets. Indeed, combination treatments or polypharmacy, targeting different disease mechanisms have consistently shown superior efficacy in transgenic ALS mice, such as the combination of rasagiline with riluzole [39].

\section{Multimodal iron chelating compounds, M30 and HLA20}

Neuroprotective effects on cell survival and signaling cascades in cell cultures

In a recent experimental study of ALS, M30 and an additional newly designed multifunctional compound, HLA20 (5-[4propargylpiperazin-1-ylmethyl]-8-hydroxyquinoline) [40] (Fig. 1) were demonstrated to possess multiple pharmacological activities in NSC-34 cells, a widely used mouse motor neuron-like cell line [36]. Initially, M30 and HLA20 were demonstrated to acquire a protective potency after exposure of cultured NSC-34 cells to the OS insults, hydrogen peroxide $\left(\mathrm{H}_{2} \mathrm{O}_{2}\right)$ and peroxynitrite generator, 3morpholinosydnonimine (SIN-1) [36], previously shown to be associated with motoneuron degeneration in ALS [41, 42]. This observation is consistent with previous studies showing that M30 decreased apoptosis of SH-SY5Y neuroblastoma cells in a neurorescue, serum deprivation model, via various protective mechanisms, including reduction of the pro- 
apoptotic proteins, Bad and Bax and inhibition of the apoptosis-associated phosphorylated H2A.X protein (Ser 139) and caspase-3 activation [33]. Since N-propargylamine and rasagiline confer neuroprotective/neurorescue effect via activation of protein kinase $\mathrm{C}$ (PKC) and mitogen-activated protein kinase (MAPK) signaling pathways, coupled to pro-survival Bcl-2 family members and mitochondrial membrane stabilization [43-45], it can be assumed that the neuroprotective effect of the novel multifunctional drugs, demonstrated in NSC-34 cells, may be partially associated with their propargyl moiety.

Effect on iron homeostasis-related proteins and hypoxia-inducible factor (HIF) pathway in cell cultures

The iron complexing moiety, embedded in the novel multifunctional iron chelating drugs may favorably influence cell survival by reducing the levels of ROS and reactive nitrogen species (RNS), due to neutralization of excessive free-reactive $\mathrm{Fe}^{2+}$. An alternative pathway of protection by iron chelators may include the inhibition of the iron-dependent hypoxia-inducible factor (HIF)- prolyl 4-hydroxylases (PHDs), enzymes that regulates HIF stability (Fig. 2) [46]. Indeed, PHDs have been suggested as an additional target for neuroprotection in various neurodegenerative diseases. Inhibition of HIF-PHDs prevents the hydroxylation and subsequent degradation of HIF-1 $\alpha$ [47]. Stabilization and nuclear localization of HIF$1 \alpha$ results in heterodimerization with its partner HIF- $1 \beta$, binding to the hypoxia-response element in the gene regulatory regions, and subsequent transcriptional upregulation of established protective genes, such as erythropoietin, vascular endothelial growth factor (VEGF), p21waf1/cip1, glycolytic enzymes (e.g. aldolase and enolase 1) as well as iron homeostasis-related proteins (e.g, TfR) [47-49]. Siddiq et al. [47] used an in vitro model of OS to correlate the protective effects of iron chelators and small molecules and peptides that don't bind iron, but do inhibit the PHDs, with their ability to activate HIF-1. This model has been further supported by the observation that the prototype iron chelating drug, desferrioxamine (DFO), was neuroprotective in hippocampal neuronal culture exposed to oxygen and glucose deprivation, in addition to OS and excitotoxicity damage, while this protection was prevented by blockade of HIF- $1 \alpha$ with antisense oligonucleotide transfection [50].

In accordance, recent study has demonstrated that M30 and HLA20 induced mRNA expression of HIF- $1 \alpha$ and enhanced the protein levels of HIF-1 $\alpha$ and its nuclear translocation in NSC-34 cells [36]. Furthermore, M30 and HLA20 significantly increased the levels of the endogenous HIF-1-dependent genes, enolase 1, VEGF, brain derived neurotrophic factor (BDNF) and TfR in NSC-34 cells (Fig. 2) [36]. Although VEGF was once considered to be only a specific angiogenic factor, emerging evidence indicates that it also has direct effects on neuronal cells and protects motoneurons from cell death induced by various insults, such as OS, hypoxia/ hypoglycemia, glutamate-excitoxicity and serum deprivation [51]. Deletion of the hypoxia-responsive element in the promotor region of the VEGF gene can cause motor degeneration in mice and low-VEGF producing alleles of the VEGF gene are associated with motoneuron degeneration in human ALS, suggesting that VEGF is a modifier of motoneuron degeneration in human ALS [52-54]. Although there is evidence for and against the role of
Fig. 2 Neuroprotective targets involved in mechanism of action of the multifunctional iron chelating compounds (e.g. M30, HLA20). Full explanation is discussed in the text. Abbreviations; brain derived neurotrophic factor (BDNF); erythropoietin (EPO); extracellular signalregulated kinase (ERK); hypoxia-inducible factor (HIF); glucose transporter 1 (GLUT-1); glycogen synthase kinase 3 (GSK-3) $\beta$; PI3K, phosphatidylinositol 3-kinase protein kinase $\mathrm{C}$ (PKC); transferrin receptor (TfR); tyrosine hydroxylase $(\mathrm{TH})$; vascular endothelial growth factor (VEGF)

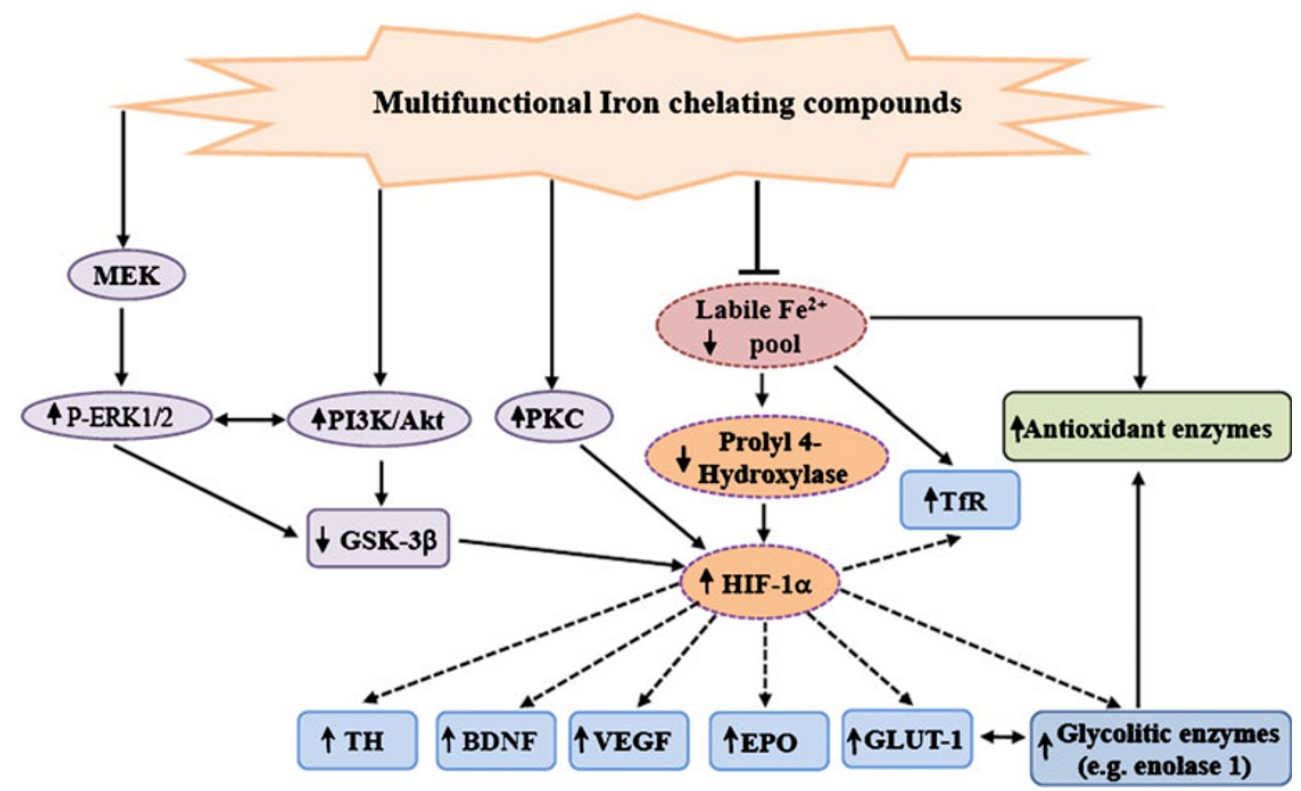


VEGF in ALS etiopathogenesis, the literature has widespread interest in developing VEGF-based therapies for motoneuron degenerative disorders, raising new hope for the treatment of ALS and other neurodegenerative diseases. Besides regulating VEGF, HIF-1 has been also shown to promote glycolytic enzyme gene expression and consequent aerobic glycolysis $[55,56]$. Recent studies have demonstrated that a shift in energy generation from glucose oxidation in mitochondria to aerobic glycolysis is associated with resistance to OS [57]. Thus, by inducing glycolytic enzyme expression, iron chelators may reduce the ambient free radical burden of neurons by enabling the cell to generate more energy glycolytically and minimize deleterious consequences of mitochondrial glucose oxidation. Taken together, it can be suggested that regulation of HIF- $1 \alpha$ expression and its related genes may constitute an additional pathway underlying the neuroprotective effect of M30 and HLA20.

In addition, it has been reported that phosphatidylinositol3-kinase $(\mathrm{PI} 3 \mathrm{~K}) /$ protein kinase $\mathrm{B}$ (AKT) signaling plays an important role in regulating $\mathrm{HIF}-1 \alpha$ expression $[58,59]$. Indeed, both M30 and HLA20 markedly increased the amount of phospho-AKT and phosphor- glycogen synthase kinase 3 (GSK-3) $\beta$ (at ser-9) [60] in NSC-34 cells, suggesting that both drugs induced activation of AKT followed by phosphorylation (inactivation) of GSK-3 $\beta$ (Fig. 2) [36].

Induction of neurite outgrowth and differentiation in cell cultures

Another important characteristic aspect of M30 and HLA20 is their ability to induce differentiation, cell elongation and stimulate neurite outgrowth of NSC-34 motoneuron cells [36]. These morphological modifications were accompanied by an increase in the immunoreactivity of the neuronal marker Growth-associated protein, GAP-43, and decrease in cyclin D1 expression [36], in accordance with results of previous studies, demonstrating that M30 induced a neuritogenic effect and triggered cell cycle arrest in G0/ G1 in rat pheochromocytoma PC12 and human SH-SY5Y neuroblastoma cell lines [33]. Indeed, many cell cycle regulating factors require iron for their function [61, 62]. Thus, an inhibitory effect of the novel iron-chelator compounds on cell cycle reentry [33], may trigger the process of differentiation through various iron-associated biological events [63]. In addition, the effect of the multifunctional drugs on motoneuron differentiation may be associated with their propargyl moiety, since Npropargylamine and rasagiline were shown to up-regulate BDNF and glial cell line-derived neurotrophic factor (GDNF) gene expression in PC12 cells [43, 45]. In in vitro studies in NSC-34 cell, M30 and HLA20 were demonstrated to induce mRNA levels of BDNF, which is a well recognized neurotrophic factor for motoneurons [36, 6466]. Motor neuron differentiation, induced by M30 and HLA20, was shown to be modulated by inhibitors of ERK/ MAPK and PKC signaling pathways (Fig. 3) [36]. In results, complementary to inhibition studies, we found that the drugs significantly increased the immunoreactivity of phosphorylated MAPK and PKC in NSC-34 cells, further indicating the involvement of both ERK and $\mathrm{PKC}$ activation [36].

Neuroprotective effects in mouse model of ALS

Treatment with M30 provided clear benefits in the fastprogressing strain of G93A-SOD1 mutant ALS transgenic mice [67] even when the treatment was initiated relatively advanced stage of the disease (at day 70th post-natal) [36]. Oral administration of M30 (1 mg/kg, 4Xwk) resulted in delaying the onset of motor dysfunction (the average age of onset was $107 \pm 3$ days in the control group, while $112 \pm$ 4 days in the M30-treated group; $n=14-16$ /group; $p<0.001$; log -rank Mantel-Cox test) and in significantly increasing their survival (an increase in survival by M30 treatment from $124 \pm 6$ to $134 \pm 12$ days; $n=14-16$ /group; $p<0.025$; log -rank Mantel-Cox test) (Fig. 4) [36]. In a supplementary study performed in G93A-SOD1 mice, initiated at presymptomatic stage of the neurological dysfunctions, M30 was demonstrated to reduce spinal motor neuronal loss (submitted for publication). M30 also inhibited the inflammatory-related factor, tumor necrosis factor- $\alpha$ (TNF $\alpha)$ by suppressing the glial activation, as well as reduced TAR-DNA binding protein (TDP-43), which is a major ubiquitinated inclusion of ALS inclusions [68,69].

\section{Natural multifunctional iron chelating compound, EGCG}

Naturally multifunctional occurring polyphenols, in particular, the major component of green tea, (-)-epigallocatechin-3gallate (EGCG) (Fig. 1) has been indicated as novel and promising therapeutic approach for treating neurodegenerative disease, including AD, PD and ALS. Indeed, several studies of acute and chronic EGCG administration in different cellular and animal models of neurodegeneration, demonstrated various novel molecular targets, including, the MAPK/ PKC and the PI3K/AKT signaling pathways; survival genes and proteins associated with mitochondrial function [70]. EGCG was demonstrates to protect ventral spinal cord 4.1 cells (VSC 4.1), motoneuron-neuroblastoma hybrid cell line, wild-type and G93A mutant cells, from $\mathrm{H}_{2} \mathrm{O}_{2}$-induced cytotoxicity and affected upstream signaling through the PI3K/Akt, GSK-3 pathway, as well as downstream cascade involved in cytochrome $\mathrm{c}$ release and 

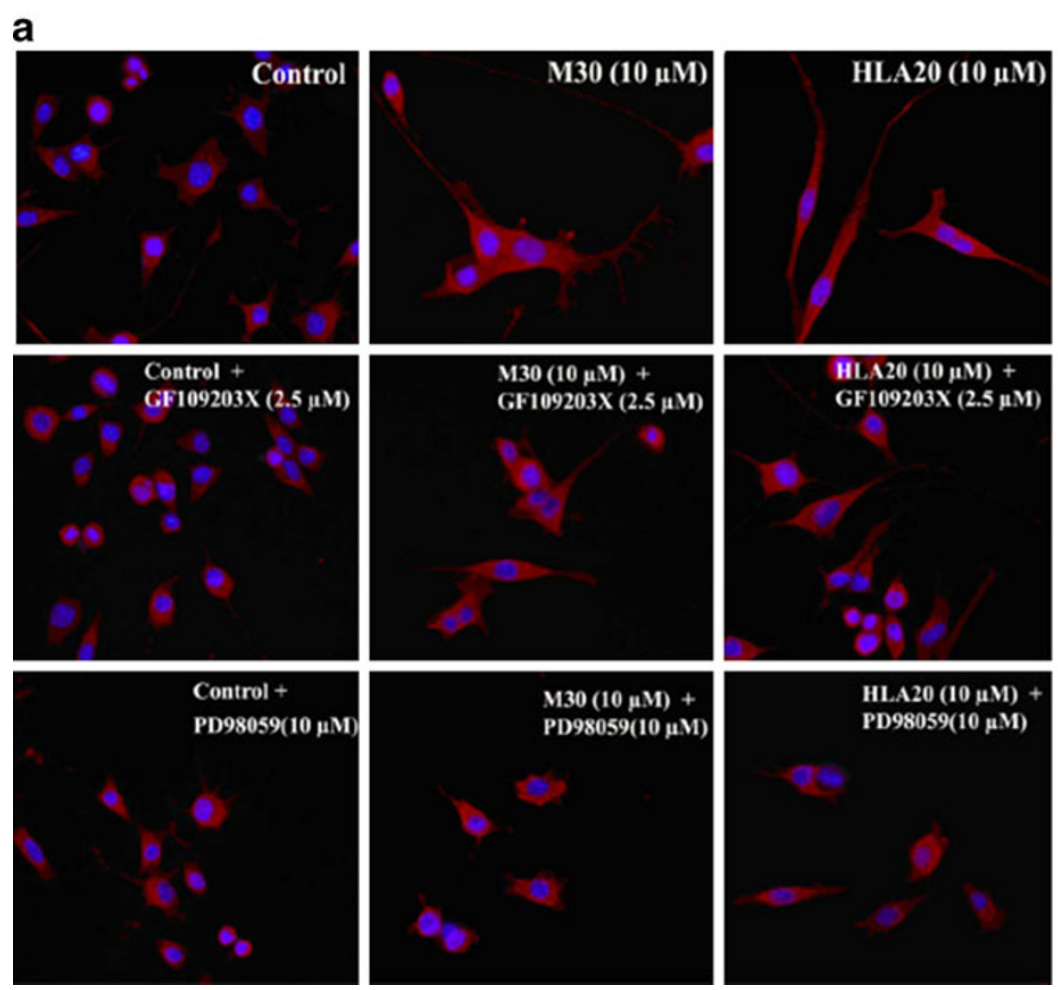

b

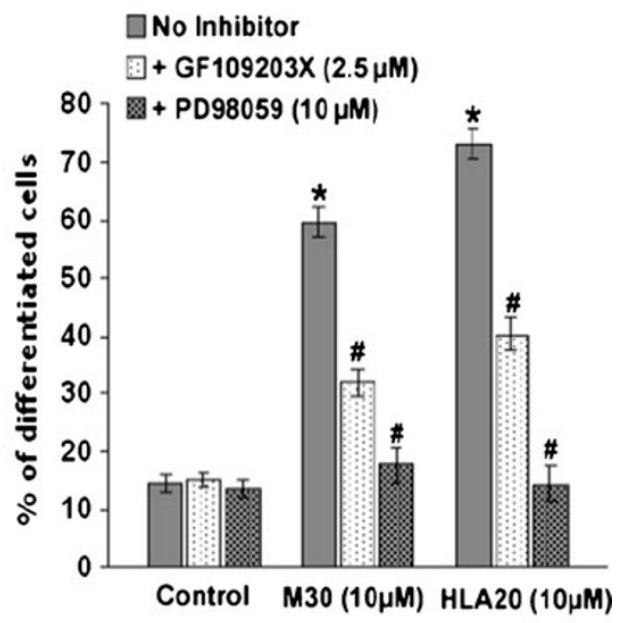

Fig. 3 Attenuation of the neuritogenic effect of M30 and HLA20 by specific inhibitors of PKC and MAPK/ERK kinase (MEK). NSC-34 cells were incubated with PKC inhibitor GF109203X (2.5 $\mu \mathrm{M})$ or MEK inhibitor PD98059 $(10 \mu \mathrm{M})$ for $1 \mathrm{~h}$ before administration of M30 $(10 \mu \mathrm{M})$ or HLA20 $(10 \mu \mathrm{M})$ for a further $24 \mathrm{~h}$. The cells were fixed and permeabilized for GAP-43 detection. a The images are

caspase-3 activation [71]. In accordance, oral administration of EGCG to G93A-SOD1 mutant transgenic mice, beginning from a pre-symptomatic stage, significantly prolonged the symptom onset, delayed the onset of disease and extended life span [71-73]. Additionally, EGCG increased the number of motor neurons, diminished microglial activation, reduced immunohistochemical reaction of NF-kappaB and cleaved caspase-3, as well as reduced protein level of iNOS and NFkappaB in the spinal cords of G93A-SOD1 mutant transgenic mice [73].

\section{Genetic and cellular therapeutic approaches in ALS patients and animal models}

The vast majority of ALS cases have not been associated with genetic factors. However, approximately $2 \%$ of all known ALS cases are attributed to mutations in the zinc/ copper superoxide dismutase (SOD1) gene [6]. To date, over 100 mutations associated with fALS have been mapped to the SOD1 gene. One of the most prevalent mutations is the G93A variant, in which the amino acid glycine is replaced by alanine at position 93. This information was used in developing animal models of representative fields from three independent experiments. b the histogram represents averages of the differentiated cell percentages $( \pm$ SEM). One-way ANOVA followed by Student's $t$-test was used for statistic analysis. ${ }^{*} p<0.001$ vs. respective controls; $\# p<0.001$ vs. M30 and HLA20 only (without inhibitors) treated cells. (Reproduced from [36])

ALS; the first and most commonly used model is of transgenic rodents harboring the G93A mutation. These animals develop a pathophysiological condition resembling ALS, presenting with hindlimb weakness at 3 to 4 months of age and progressive paralysis culminating in death at the age of 4 to 5 months. The pathological features of the disease resemble human neurologic diseases, including loss of large spinal cord motoneurons and robust spinal astrogliosis and microgliosis [5, 67]. Other genes linking

Fig. 4 Effect of M30 treatment on motor dysfunction onset, survival time, motor deficits and weight in G93A-SOD1 mutant ALS transgenic mice. Mutant G93A-SOD1 mice were treated by the oral gavage method with vehicle (control) or M30 (1 mg/kg) four times a week starting from the 70th day after birth and continuing until death. Plots present cumulative probability of a the symptoms onset $(n=13-16$ per group; $p<0.001 ; \log$-rank Mantel-Cox test) and b overall survival $(n=13-16$ per group; $p<0.025$; log -rank Mantel-Cox test) against the age of the mutant mice. Histograms present $\mathbf{c}$ mean onset (days) and $\mathbf{d}$ mean survival (days) of vehicle- or M30-treated G93A-SOD1 mice. Values are means \pm SEM $\left(n=13-16\right.$ per group; ${ }^{*} p<0.05, * * p<0.001$ vs. control group; one-way ANOVA). e Overall neurological deficit scores vs. the age of animals. The total neurological deficits were determined from four independent tests (rotarod performance, postural reflex, screen grasping and tail suspension behavior). Total score of 12 represent a complete loss of motor function. Values are means \pm SEM ( $n=13-16$ per group). $\mathbf{f}$ Weight vs. the age of animals. Values are means \pm SEM. (Reproduced from [36]) 
a

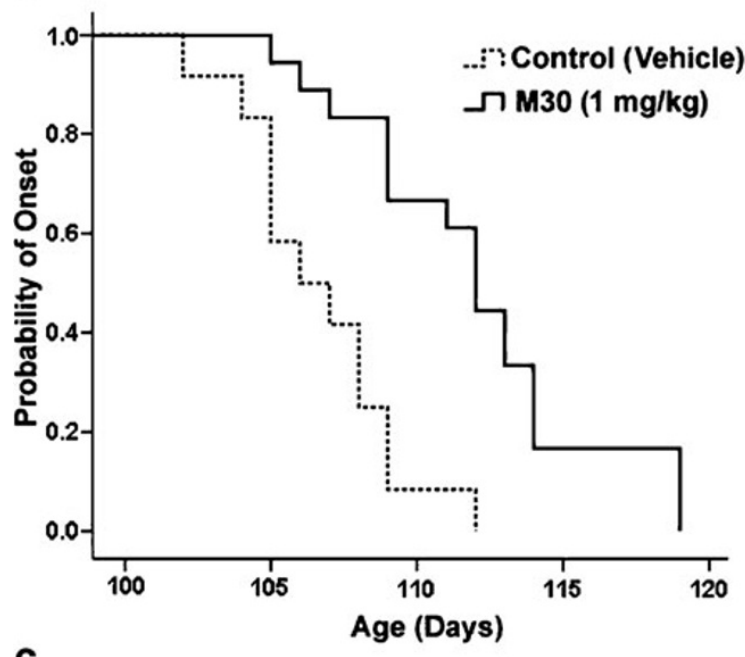

C

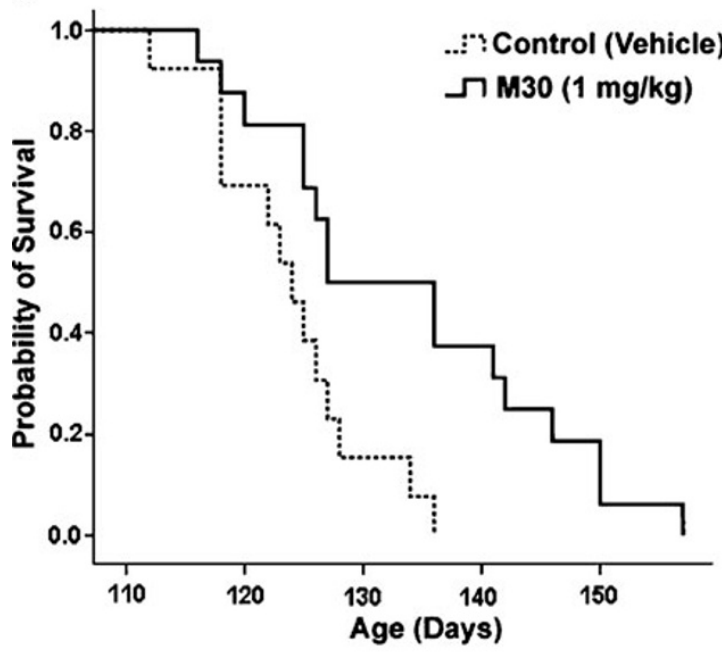

e

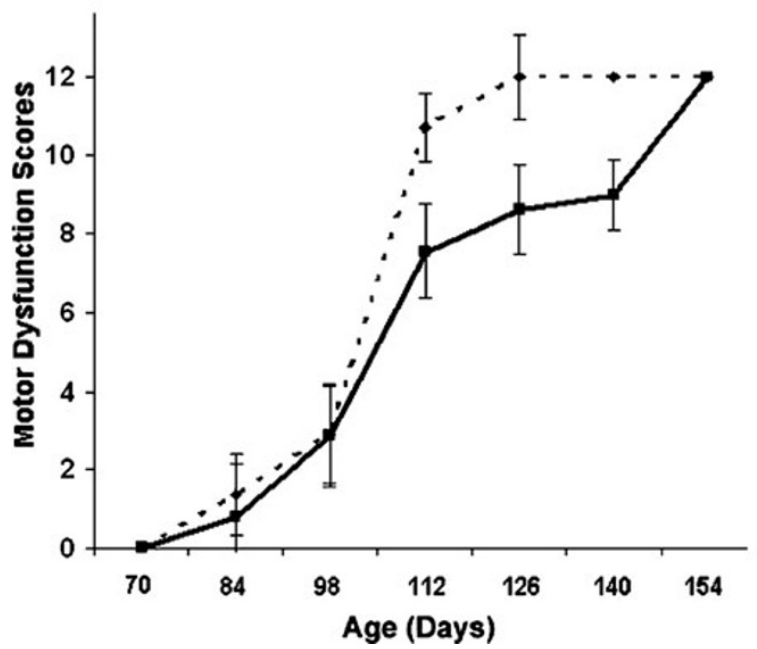

b

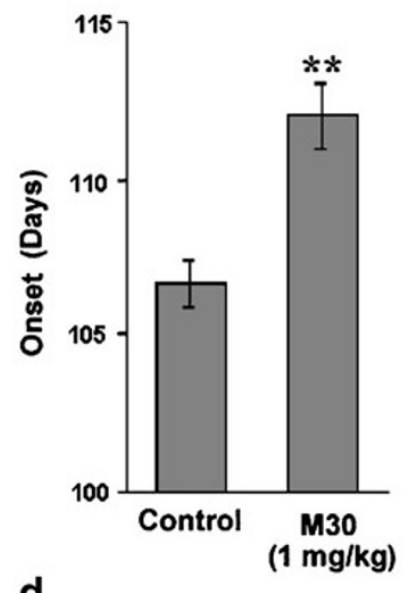

d
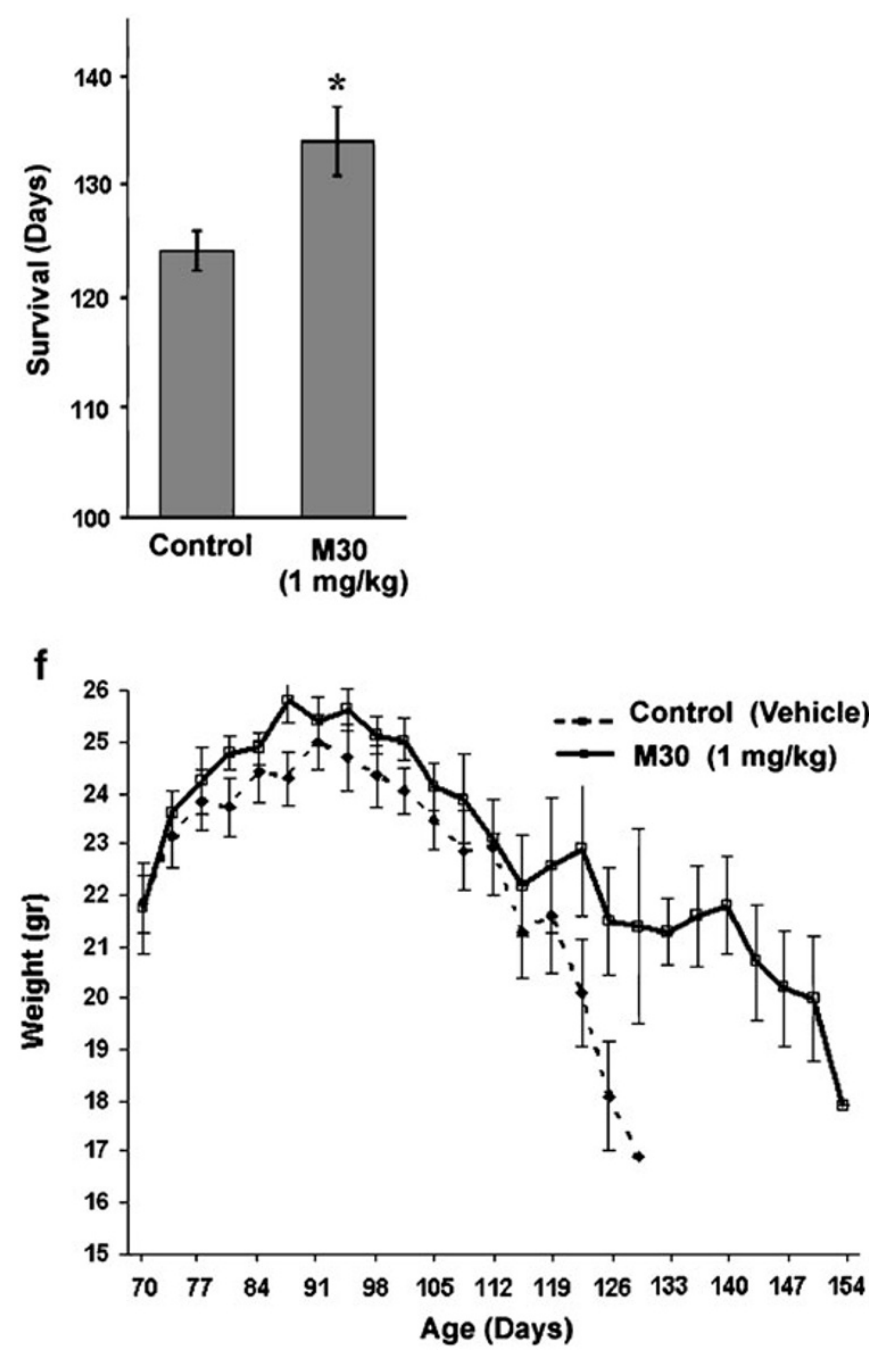


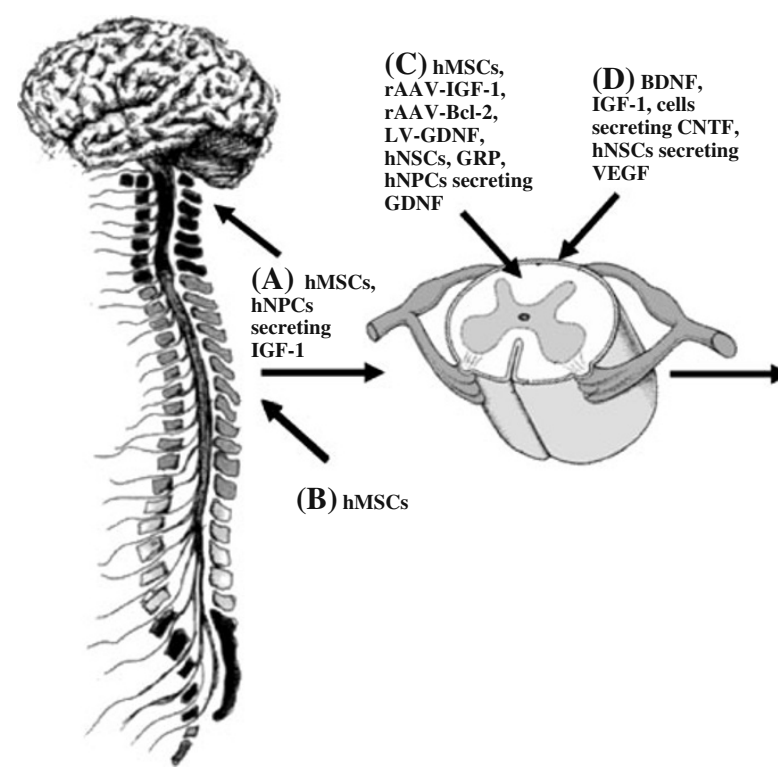

Fig. 5 A schematic representation of methods allowing local delivery of neurotrophic factors and cellular transplantations performed in ALS animal models and patients. a Represents the cisterna magna. b Refers to the CSF. c Concerns intraspinal treatment. d Indicates the spinal intrathecal space. e Pertains to the intramuscular space. Abbreviations;

to fALS include alsin (ALS2), senataxin (ALS4), vesicle associated membrane protein (VAPB, ALS8), angiogenin and a mutation in the p150 subunit of dynactin [2]. Recently, mutations in TARDBP gene, encoded the TAR-DNA binding protein TDP-43 and located on chromosome $1 \mathrm{p} 36.22$, have been reported to be associated with fALS and SALS [2].

In the next section, we will focus on genetic therapies, cell replacement therapies and their combination. We will further review experiments, performed predominantly in the SOD1 rodent ALS models and later adapted for clinical trials (Fig. 5; Table 1).

\section{Adeno-associated viruses}

Adeno-associated viruses (AAVs) are small single strand DNA genome encapsidated viruses, which require helper viruses for successful infection and are therefore not themselves pathogenic [117, 118]. Recombinant AAVs (rAAVs) are produced by replacing their pathogenic viral DNA with the gene of interest.

Injecting rAAVs containing either IGF-1 or GDNF into respiratory and motor limb muscle terminals of SOD1 G93A mice delayed disease onset, prolonged life and moderated disease progression. IGF-1 was found to perform more potently than GDNF. It was further established that the rAAVs selectively transfected motoneurons without infecting neighboring glia cells. To assess the importance of rAAVs retrograde delivery into the central human mesenchymal stem cells (hMSCs), human neuronal progenitor cells (hNPCs), recombinant Adeno-associated virus (rAAV), lentivirus (LV), human neuronal stem cells (hNSCs), glial restricted precursors (GRP), tetanus toxin heavy chain (TTC), fusion protein of IGF-1 and TTC (IGF-1:TTC), fusion protein of GDNF and TTC (GDNF:TTC)

nervous system (CNS), SOD1 mice were transfected with recombinant lentiviruses (rLVs) containing IGF-1 which were not retrogradely transported and were found to increase survival to a lesser extent than rAAV-IGF-1 [90]. Similar results were obtained when rAAVs containing IGF1 were delivered to the deep cerebellar nuclei [89]. Spinal cord infection was accompanied by a sexual bias predominantly effecting male mice [91, 92]. Additional research on rAAVs carrying GDNF, injected intramuscularly, further emphasized its therapeutic potential, as long term GDNF expression in the CNS, a delay in disease onset, an amelioration in disease progression and a prolongation of life expectancy, were obtained [93, 119].

Neurotrophic factors are not the only genes that can be delivered using viral vectors. Bcl-2 an anti-apoptotic protein has previously been delivered to the lumber spinal cord of SOD1 G93A mice using a rAAV construct. Intraspinal injection of these rAAVs resulted in sustained motoneuron Bcl-2 expression, delayed disease onset and significantly increased the number of surviving motoneurons at disease end-stage, but was ultimately unable to prolong survival [94]. This represents an interesting alternative for gene selection in AAV based gene therapy in ALS. However, when considering this approach we must be extremely vigilant regarding the transfected cells, as the effect of Bcl-2 might be a double edged sword, protective in non-dividing, degeneration prone motoneurons, yet potentially oncogenic in other cells.

rAAVs are emerging as a prominent vector for neurotrophic factor gene delivery in ALS, probably due to their 
Table 1 An overview of several genetic and cellular therapeutic approaches relating to ALS patients and animal models

\begin{tabular}{|c|c|c|c|c|}
\hline Method of treatment & Treated group & Method of delivery & Effect & Reference \\
\hline $\begin{array}{l}\text { Recombinant methionyl } \\
\text { BDNF }\end{array}$ & $\begin{array}{l}\text { Clinical trails ALS } \\
\text { patients. }\end{array}$ & Intrathecal administration & No clinical or survival benefits. & {$[74-76]$} \\
\hline Recombinant IGF-1 & $\begin{array}{l}\text { Clinical trails ALS } \\
\text { patients. }\end{array}$ & Subcutaneous administration & $\begin{array}{l}\text { American trial: slower progression } \\
\text { of functional impairment. } \\
\text { European trial: no clinical benefits. }\end{array}$ & {$[77,78]$} \\
\hline Recombinant IGF-1 & $\begin{array}{l}\text { Clinical trails ALS } \\
\text { patients. }\end{array}$ & Intrathecal infusion & Modest beneficial effects. & {$[79]$} \\
\hline $\begin{array}{l}\text { Recombinant human } \\
\text { CNTF }\end{array}$ & $\begin{array}{l}\text { Clinical trails ALS } \\
\text { patients. }\end{array}$ & Subcutaneous injections & $\begin{array}{l}\text { No beneficial clinical results, high } \\
\text { dose CNTF administration was } \\
\text { accompanied by severe adverse } \\
\text { reactions and an increased } \\
\text { number of deaths. }\end{array}$ & {$[80-82]$} \\
\hline Human MSCs & $\begin{array}{l}\text { Clinical trails ALS } \\
\text { patients. }\end{array}$ & $\begin{array}{l}\text { Intraparenchymal autologous } \\
\text { transplantation at the thoracic } \\
\text { level of the spinal cord }\end{array}$ & $\begin{array}{l}\text { Contradicting results of ether slight } \\
\text { clinical improvement or no } \\
\text { clinical benefits. }\end{array}$ & {$[83,84]$} \\
\hline Human HSCs & $\begin{array}{l}\text { Clinical trails sporadic } \\
\text { ALS patients }\end{array}$ & $\begin{array}{l}\text { Post-irradiation transplantation } \\
\text { with a sibling's HSCs }\end{array}$ & No clinical benefits. & {$[85]$} \\
\hline $\begin{array}{l}\text { Baby hamster kidney } \\
\text { cells overexpressing } \\
\text { CNTF }\end{array}$ & $\begin{array}{l}\text { Clinical trails ALS } \\
\text { patients. }\end{array}$ & $\begin{array}{l}\text { Intrathecal transplantation of } \\
\text { membrane encapsulated cells }\end{array}$ & $\begin{array}{l}\text { Clinical benefits have not been } \\
\text { reported. }\end{array}$ & {$[86-88]$} \\
\hline rAAV-IGF-1 & SOD1 G93A mice & $\begin{array}{l}\text { rAAV-IGF-1 at respiratory and } \\
\text { motor limb muscles or deep } \\
\text { cerebellar nuclei }\end{array}$ & $\begin{array}{l}\text { Delayed disease onset, prolonged } \\
\text { life and moderated disease } \\
\text { progression. }\end{array}$ & {$[89,90]$} \\
\hline rAAV-IGF-1 & SOD1 G93A mice & $\begin{array}{l}\text { rAAV-IGF-1 Spinal cord } \\
\text { infection }\end{array}$ & $\begin{array}{l}\text { Delayed disease onset, weight loss, } \\
\text { decline in hindlimb grip strength } \\
\text { and increased survival was } \\
\text { observed in male but not female } \\
\text { mice. }\end{array}$ & {$[91,92]$} \\
\hline rAAV-GDNF & SOD1 G93A mice & $\begin{array}{l}\text { rAAV-GDNF at respiratory and } \\
\text { motor limb muscles }\end{array}$ & $\begin{array}{l}\text { Delayed disease onset, prolonged } \\
\text { life and moderated disease } \\
\text { progression. }\end{array}$ & [93] \\
\hline rAAV-GDNF & SOD1 G93A mice & $\begin{array}{l}\text { rAAV-GDNF intramuscularly } \\
\text { injecting }\end{array}$ & $\begin{array}{l}\text { Delayed disease onset, } \\
\text { amelioration of disease } \\
\text { progression and prolongation } \\
\text { of life expectancy. }\end{array}$ & {$[93]$} \\
\hline rAAV-Bcl-2 & SOD1 G93A mice & $\begin{array}{l}\text { Lumber spinal cord } \\
\text { rAAV-Bcl-2 infection }\end{array}$ & $\begin{array}{l}\text { Delayed disease onset and } \\
\text { preservation of spinal } \\
\text { motoneurons. }\end{array}$ & {$[94]$} \\
\hline LV-GDNF & $\begin{array}{l}\text { SOD1 G93A mice and } \\
\text { facial motoneurons } \\
\text { axotomy model. }\end{array}$ & $\begin{array}{l}\text { LV-GDNF lumber spinal cord } \\
\text { and facial nucleus injections }\end{array}$ & $\begin{array}{l}\text { Rescue of motoneurons in the } \\
\text { facial nucleus. No effect on } \\
\text { spinal motoneurons. }\end{array}$ & {$[95,96]$} \\
\hline LV-VEGF & SOD1 G93A mice & $\begin{array}{l}\text { LV-VEGF infection at muscle } \\
\text { terminals }\end{array}$ & $\begin{array}{l}\text { Delayed disease onset, slower } \\
\text { disease progression and } \\
\text { prolonged survival. }\end{array}$ & {$[97]$} \\
\hline TTC & SOD1 G93A mice & $\begin{array}{l}\text { Intramuscular injections of } \\
\text { naked TTC DNA }\end{array}$ & $\begin{array}{l}\text { Delayed onset of symptoms and } \\
\text { functional deficits, improved } \\
\text { spinal motor neuron survival, and } \\
\text { prolonged lifespan. }\end{array}$ & [98] \\
\hline IGF-1:TTC & SOD1 G93A mice & $\begin{array}{l}\text { Intramuscular and intrathecal } \\
\text { injections of soluble IGF-1: } \\
\text { TTC protein }\end{array}$ & No significant clinical effect. & [99] \\
\hline GDNF:TTC & SOD1 G93A mice & $\begin{array}{l}\text { Intramuscular injections of } \\
\text { soluble GDNF:TTC protein }\end{array}$ & Mild survival prolongation. & {$[100]$} \\
\hline Human NSCs & SOD1 G93A rats & $\begin{array}{l}\text { Lumbar spinal cord } \\
\text { transplantation }\end{array}$ & $\begin{array}{l}\text { Delayed disease onset and } \\
\text { prolongation of life expectancy. }\end{array}$ & {$[101,102]$} \\
\hline $\begin{array}{l}\text { Glial restricted } \\
\text { precursors }\end{array}$ & SOD1 G93A rats & $\begin{array}{l}\text { GRP transplantation at cervical } \\
\text { spinal cord respiratory motor } \\
\text { neuron pools }\end{array}$ & $\begin{array}{l}\text { Extended survival and disease } \\
\text { duration, attenuated motor } \\
\text { neuron loss and moderated } \\
\text { decline in forelimb motor and } \\
\text { respiratory functions. }\end{array}$ & {$[103,104]$} \\
\hline Human MSCs & SOD1 G93A mice and & lumber spinal cord, cisterna & Extended survival, reduced & [105-107] \\
\hline
\end{tabular}


Table 1 (continued)

\begin{tabular}{|c|c|c|c|c|}
\hline Method of treatment & Treated group & Method of delivery & Effect & Reference \\
\hline & rats & $\begin{array}{l}\text { magna and CSF } \\
\text { transplantations }\end{array}$ & $\begin{array}{l}\text { neuroinflammation; astrogliosis } \\
\text { and microgliosis and ameliorated } \\
\text { disease symptoms. }\end{array}$ & \\
\hline Human MSCs & SOD1 G93A mice & $\begin{array}{l}\text { Post irradiation intravenous } \\
\text { administration }\end{array}$ & $\begin{array}{l}\text { Delayed disease onset, delayed } \\
\text { disease progression and increased } \\
\text { lifespan. }\end{array}$ & {$[108]$} \\
\hline Bone marrow cells & $\begin{array}{l}\text { A crossbred of PU.1-/- } \\
\text { mice and SOD1 } \\
\text { G93A mice }\end{array}$ & Bone marrow transplantation & $\begin{array}{l}\text { Reduced motoneuron } \\
\text { degeneration, ameliorated disease } \\
\text { progression and prolonged } \\
\text { survival. }\end{array}$ & [109] \\
\hline Bone marrow cells & SOD1 G93A mice & $\begin{array}{l}\text { Post-irradiation intra-bone } \\
\text { marrow grafts }\end{array}$ & $\begin{array}{l}\text { Slowed disease progression and } \\
\text { extended survival. }\end{array}$ & {$[110]$} \\
\hline $\begin{array}{l}\text { Human umbilical } \\
\text { cord blood cells }\end{array}$ & SOD1 G93A mice & Retro-ocular transplantation & $\begin{array}{l}\text { Delayed disease onset and } \\
\text { extended survival. }\end{array}$ & [111] \\
\hline $\begin{array}{l}\text { Human NPCs secreting } \\
\text { GDNF }\end{array}$ & $\begin{array}{l}\text { SOD1 G93A mice and } \\
\text { rats }\end{array}$ & Spinal cord grafts & $\begin{array}{l}\text { Delayed disease onset but did not } \\
\text { extended survival. }\end{array}$ & [112-114] \\
\hline $\begin{array}{l}\text { Human MSCs secreting } \\
\text { GDNF }\end{array}$ & SOD1 G93A rats & Muscle transplantations & $\begin{array}{l}\text { Delayed disease progression and } \\
\text { extended overall life span. }\end{array}$ & [115] \\
\hline $\begin{array}{l}\text { Human NSCs } \\
\text { overexpressing VEGF }\end{array}$ & SOD1 G93A mice & $\begin{array}{l}\text { Intrathecal transplantation into } \\
\text { the lumber spinal cord }\end{array}$ & $\begin{array}{l}\text { Delayed disease onset, slower } \\
\text { decline of motor function and } \\
\text { prolonged survival. }\end{array}$ & {$[116]$} \\
\hline $\begin{array}{l}\text { Human NPCs secreting } \\
\text { IGF-1 }\end{array}$ & SOD1 G93A mice & $\begin{array}{l}\text { Intrathecal transplantation into } \\
\text { the cisterna magna }\end{array}$ & $\begin{array}{l}\text { Enhanced motor neuron survival, } \\
\text { but with no functional } \\
\text { improvement or extension } \\
\text { of life span. }\end{array}$ & {$[113]$} \\
\hline
\end{tabular}

Abbreviations: MSCs Mesenchymal stem cells, NPCs neuronal progenitor cells, NSCs neuronal stem cells, GRP glial restricted precursors, $r A A V$ recombinant Adeno-associated virus, $L V$ lentivirus, TTC tetanus toxin heavy chain, IGF-1:TTC fusion protein of IGF-1 and TTC, GDNF:TTC, fusion protein of GDNF and TTC

many advantages, which include rare vector sequence integration into host genome, efficient transfection of both dividing and non-dividing cells, long-term gene expression, low risk of toxicity, and minimal stimulation of the host immune response. The existence of several serotypes allows differential targeting of specific CNS cell populations [92]. However, they are limited by the relatively small amount of DNA they can encapsulate, thus not suitable for larger genetic constructs [118].

\section{Lentiviruses}

Lentiviruses (LVs) are the most complex viruses in the retroviral family and are particularly suitable for CNS related genetic therapy. Lentiviral vectors have relatively large RNA packing capacity. They can efficiently transfect not only dividing but also non dividing cells, such as neurons. LVs can reverse transcribe their RNA into the host cell's DNA, thus promoting stable and long term expression of the gene of interest [117, 120-122].

Recombinant LVs for gene therapy are produced similarly to rAAVs. First, removal of as much of the viral genes as possible occurs, then the desired expression cassette is inserted. rLVs incapable of producing a functional envelope can be pseudotyped with different viruses to selectively direct the infection to the desired cellular type and prevent secondary infection [123, 124].

Lumber spinal cord and facial nucleus injections of rLVs incorporating the GDNF gene were found to significantly rescue motoneurons in the facial nucleus, but did not prevent spinal motoneuron loss, despite robust intraspinal GDNF expression in SOD1 G93A mice and facial motoneurons axotomy mice models [95, 96].

Injection of a recombinant rabies-G pseudotyped lentiviral vector based on the equine infectious anemia virus encoding the human vascular endothelial growth factor (hVEGF) gene at several muscle terminals in SOD1 G93A mice, promoted hVEGF expression in spinal cord motoneurons, delayed disease onset, slowed disease progression and prolonged survival [97].

\section{Tetanus toxin heavy chain}

Gene therapy can also be based on non-viral delivery of naked DNA. It has been suggested that the non-toxic carboxyterminal fragment of the tetanus toxin heavy chain (TTC) can act as a neuroprotective agent through the downregulation of caspases 1 and 3. Intramuscular injections of naked DNA encoding the TTC gene in SOD1 G93A mice delays the onset of symptoms and functional deficits, improved spinal motor 
neuron survival, and prolonged lifespan [98]. TTC has also been used as a platform for delivering IGF-1 and GDNF to motoneurons. Intrathecal and intramuscular injections of a soluble IGF-1: TTC fusion protein had no significant effect on disease progression or survival in SOD1 G93A mice [99]. However, a slight increase in survival was noted when similar intramuscular injections of a GDNF:TTC fusion protein in SOD1 G93A mice were administered [100].

Genetic therapy approaches offer promising strategies for delivering factors that might enhance the survival chances of degeneration prone neurons in ALS. However, it is not the only option: transplantation of whole cells presents a viable and potent non-viral alternative.

\section{Motor neuron replacement therapies}

Motor neurons can be effectively derived from embryonic stem cells (ESCs), neuronal stem cells (NSCs) and induced pluripotent stem (iPS) cells [125-127]. The strategy for treatment is to use these cells to replace the neurons afflicted in ALS.

In several studies of neuronal transplantations, performed in mice and rat models of ALS, a delay in disease onset and a mild prolongation of life expectancy have been observed [127-129].

It has been further shown that human NSCs grafted into the lumbar spinal cord of SOD1 G93A rats, survive after transplantation and present with predominantly neuronal differentiation at the transplantation site. The grafts secrete BDNF and GDNF, while forming functional synapses with host motor and non-motor neurons. However, the differentiated neurons do not develop into large motor neurons, but are predisposed to a GABAergic phenotype. A mild delay in disease onset and prolongation of life expectancy have been observed [101, 102].

The limited in vivo axonal growth rate of grafted motoneurons derived from ESC [126] hinders their viability as candidates for replacement therapy in neurodegenerative diseases such as ALS. The observed therapeutic effects of neuronal stem cells in these experiments could be attributed to their neuron to neuron trophic functions, such as buffering glutamate levels and neurotrophic factor delivery $[102,130]$. In this case, whether motor neurons are best suited to provide such effects, or whether other cell types, such as astrocytes or microglia might provide a more potent tool, must be discussed.

\section{Astroglial replacement therapies}

Astrocytic abnormalities participate in the degeneration occurring in ALS [131-134]. Furthermore, astrocytes possess potent neuroprotective potential [135]. Taken together, these attributes render astrocytes interesting targets in ALS related therapeutic strategies.

Transplantation of healthy rat and mice glial restricted precursors (GRPs) around cervical spinal cord respiratory motor neuron pools of SOD1 G93A rats, extended survival and disease duration, attenuated motor neuron loss and moderated the decline in forelimb motor and respiratory functions. These effects correlated with reduced microgliosis at the transplantation site and were severely hindered when there was an absence of GLT1, the glutamate transporter, in the cells grafted [103, 104].

These results suggest some potential for glial replacement therapies that should be further investigated.

Another potential cellular source for motor neuron protection is bone marrow derived mesenchymal stem cells (MSCs). MSCs are self-renewing precursors that can be differentiated in vitro to give rise to cells from multiple lineages, including but not limited to neuron, oligodendrocyte and astrocyte like cells [136-138]. The use of MSCs as the cellular source for stem cell based treatments not only circumvents ethical concerns but further provides candidates for autologous transplantation.

Several studies have shown that human MSCs (hMSCs), survive after transplantation into the lumber spinal cord. The cisterna magna and the CSF for long periods of time, show limited migration into and within the spinal cord, extend survival, reduce neuroinflammation; astrogliosis and microgliosis, perform moderate differentiation into neurons and astrocytes and ameliorate disease symptoms in mice and rat SOD1 G93A models [105-107].

A different approach utilizes irradiation in order to improve hMSC engraftment into the brain and muscles [139]. Intravenous administration of hMSC in irradiated pre-symptomatic SOD1-G93A mice has yielded similar results to those previously mentioned, with additional aspects of neuroglial differentiation and migration into the brain and spinal cord parenchyma [108].

Mazzini et al. performed two clinical trials [83, 84] in which MSC were autologously transplanted intraparenchymally at the thoracic level of the spinal cord of ALS patients. A total of 19 patients have been grafted in both experiments. Patients were monitored for up to 4 years and no significant acute or late side effects were evident. In most cases, no modifications of spinal cord volume or other signs of spinal or brain abnormal cell proliferation, were observed. However, in 4 of the cases the spinal cord was tethered anteriorly and posteriorly by postoperative scarring, producing marked distortion of the cord due to traction. In the first trial, the linear decline of the forced vital capacity was significantly moderated in 4 of the 9 transplanted patients. However, in second trial, slower deterioration was observed in only 2 of the 10 grafted patients. The results suggest that hMSC might 
be considered as candidates for stem cell based treatment of ALS. Moreover, intraspinal injection of MSCs showed no long term adverse outcome. Additional clinical trials have recently been launched.

Several mechanisms have been proposed to explain the neuroprotective effect observed in transplantations of native and differentiated MSC including cell replacement, immunomodulation and trophic factor delivery. hMSC can be further utilized as a platform for delivering neurotrophic factors to target areas within the brain.

When considering the use of any stem cell grafts in the future treatment of ALS, it must be noted that there is a risk of tumor formation, non-specific differentiation and long term toxic effect in these cells. One of the most prominent advantages in selecting MSC in this respect is their relative safety [140]. However, MSC derived from ALS patients might sustain disease related damages [141, 142]. Thus, autologous transplantations could be contaminated with cells impaired in their ability to counteract disease pathophysiology and result in loss of treatment effectivity. The limited migration performed by hMSC means that transplantations must take place in the already afflicted spinal cord of ALS patients, posing a difficulty. These problems must be addressed so as to be overcome in future treatments.

\section{Microglia replacement therapies}

Neurons and astrocytes are not the only cells suspected as impaired in ALS. Microglia specifically, and the immune system in general have been implicated in disease pathophysiology [143-147]. In fact, exposure of primary rat spinal cord cultures to immunoglobulin Gs (IgGs) isolated from ALS patient lead to motor neuron apoptosis [143]. When intraperitoneally injected into healthy mice, ALSIgGs caused spinal cord microglia recruitment and motor neuron degeneration $[148,149]$. PU. $1^{-/}$mice are impaired in their ability to develop myeloid and lymphoid cells and therefore lack CNS microglia. These mice were crossbred with SOD1 G93A mice and subsequently transplanted with donor wild type bone marrow cells. Donor cells differentiated into microglia and integrated into the CNS. Grafted mice benefited from reduced motoneuron degeneration, ameliorated disease progression and prolonged survival compared to mice transplanted with SOD1 G93A bone marrow cells and SOD1 G93A non-crossbred and non-transplanted mice [109]. Similar results were obtained when SOD1 G93A mice were irradiated and then intra-bone marrow grafted with wild type bone marrow cells [110] and when SOD1 mice retro-ocularly received human umbilical cord blood cells [111]. These findings prompted a clinical trial where 6 sporadic ALS patients underwent full body irradiation and were then infused with a siblings' hematopoietic stem cells (HSCs). Unfortunately, clinical benefits were not evident. Nevertheless, the experiment was not completely unsuccessful: grafted cells were found in post mortem autopsy brain and spinal cord samples. Biases in HSCs engraftment were observed, indicating that the cells gravitate towards areas of motoneuron injury and neuroinflammation [85].

Yet, it is possible that with alternative grafting techniques or cellular genetic engineering microglial cells therapeutic potential might be enhanced.

\section{Genetically altered cells}

Using gene therapy technology to enhance the neuroprotective performance of stem cells prior to their transplantation might offer a potential therapeutic tool.

Neuronal progenitor cells (NPCs), NSCs and hMSCs are only a small portion of the cellular sources that can be utilized for this purpose [112-116, 150, 151]. A vast variety of genes could also be considered as genetic targets for cellular enhancement, the most prominent of which are neurotrophic factors and glutamate transporters.

Neurotrophic factors are a group of proteins essential for neuronal development and survival. Delivery of appropriate neurotrophic factors to the immediate environment of afflicted neurons in ALS might improve their survival and thus ameliorate disease progression and symptoms.

\section{Glial cell line derived neurotrophic factor (GDNF)}

Treatment with GDNF has shown interesting results in several different neurodegenerative diseases models [151-154]. However, spinal cord grafting of GDNF secreting cells in ALS animal models appears to influence predominantly disease onset rather than progression [112-114]. Therefore, other neurotrophic factors might be better suited for ALS. On the other hand, preliminary results suggest that direct muscle delivery of GDNF, by genetically engineered hMSC, delayed disease progression and improved the overall life span [115]. In light of these results, the delivery site of GDNF rather than the neurotrophic factor itself, must be investigated as a factor in clinical outcome [155]. GDNF based treatments might be suitable as complementary to other neurotrophic factors.

\section{Vascular endothelial growth factor (VEGF)}

Deletion of the hypoxia response element sequence in the vascular endothelial growth factor (VEGF) promoter in otherwise healthy mice results in adult-onset muscle 
weakness due to the degeneration of lower motor neurons innervating skeletal muscle fibers, reminiscent of the clinical symptoms and neuropathology observed in ALS [156]. Furthermore, crossbreeding of SOD1 G93A mice with mice overexpressing VEGF in their motor neurons attenuates motor impairment, delays motoneuron loss and prolongs the survival of SOD1 G93A mice [157]. These findings closely link ALS with VEGF and highlight its therapeutic potential. Human NSCs (hNSCs) overexpressing VEGF were intrathecally transplanted into the lumber spinal cord of SOD1 G93A mice. Grafted cells survive for at least 4 weeks in the diseased spinal cord and migrate into the gray matter of the spinal cord. A small portion of grafted cells differentiated into motoneurons. Transplanted animals benefited from delayed disease onset, slower decline of motor function and prolonged survival [116]. The manner by which these cells exert their therapeutic effect remains to be determined. However, several mechanisms might be proposed. VEGF's neurotrophic function is one possibility, which includes anti-apoptotic effect on motoneurons, encouragement of neovascularization [158-160] and VEGF's protection against glutamate excitotoxicity $[161,162]$. While only few cells differentiated into motoneurons, the possibility of neuronal replacement should not be discounted altogether.

\section{Insulin like growth factor type 1 (IGF-1)}

Despite promising results in subcutaneous administration of insulin like growth factor type 1 (IGF-1) in animal models of ALS [163, 164], similar clinical trials have been found wanting $[77,78,165]$. Yet, modest beneficial effects were obtained in high dose intrathecal administration of IGF-1 in ALS patients [79].

Localized and continues delivery of IGF-1, via genetically enhanced cells could lower the necessary IGF-1 dosage thus reducing side effects and improving the therapeutic outcome. Recently, human NPCs (hNPS) have been adenovirally infected with the IGF-1 gene, to induce IGF-1 secretion. Transplantation of these cells into the cisterna magna of SOD1 G93A mice, showed enhanced motoneuron survival, but no functional improvement or extension of life span [113].

\section{Ciliary neurotrophic factor (CNTF)}

Another factor that has been examined for therapy is the ciliary neurotrophic factor (CNTF). Unfortunately, clinical trials systemically delivering CNTF caused severe adverse reactions in ALS patients [80-82]. In an attempt to reduce unwanted CNTF related side effects, baby hamster kidney cells were genetically engineered to overexpress CNTF, encapsulated in a semispherical membrane and intrathecally implanted in the lumber spinal cord of ALS patients. The membrane allows for passage of nutrients and cell-released therapeutic agents, but restricts diffusion of larger molecules and cells, thus facilitating graft survival and enabling the retrieval of the transplanted cells in the event of severe side effects or oncogenic developments. A robust CNTF presence could be detected for several weeks following transplantation in the CSF of most patients. Grafts survive for up to 20 weeks in the absence of immunosuppression, but an antigenic reaction to bovine fetuin, a component of preimplantation medium was observed. However, neither CNTF nor the presence of antibodies against bovine fetuin, elicited any adverse side effects in the implanted patients. However, clinical benefits have not been reported [86-88].

\section{Glutamate transporters}

A different approach to genetically engineered cells considers increasing glutamate removal from the neuronal environment rather than infusion of neurotrophic factors. Glutamate is the main excitatory amino acid (a.a) neurotransmitter in the human central nervous system (CNS). It plays a major role in synaptic plasticity, learning, development, cognitive functions and human behavior [166-170]. However, when glutamate is not properly controlled, it may lead to detrimental results. Prolonged exposure to glutamate can promote a process culminating in neuronal cell death $[82,150,166,167,169$, 171-173]. Accumulating evidence implicates glutamate excitotoxicity in the pathophysiology of ALS. Furthermore, RNA editing impairments and a significant reduction in the expression and activity of the glutamate transporter GLT1 in animal models of ALS and its human counterpart EAAT2 in patients has been noted [174-178]. We can thus propose that reducing extracellular glutamate levels around the susceptible neurons affected by glutamate toxicity in ALS may mitigate the neurodegenerative progression of the disease. Crossbreeding of SOD1 G93A mice with astrocyte overexpressing human EAAT2 mice, improved motor performance, protected motoneurons from glutamate induced excitotoxicity but did not delay the onset of paralysis nor did it prolong life span [179]. Transplantation of cells over-expressing GLT1 in animal models of ALS should be investigated to maximize the therapeutic potential of this approach.

\section{Conclusions and future perspectives}

To date there is no treatment that can substantially prolong life expectancy in individuals afflicted with ALS. Never- 
theless where current drug treatments have failed, gene therapy, cell replacement therapies or a combination of both, could offer improved alternatives. Also, trophic factors, known for their role in the survival, development and maintenance of motor neurons [180-186] have been considered as potential therapeutic agents in ALS. Encouraging preliminary results using neurotrophic factors in animal models has prompted further research. Unfortunately, in clinical trials subcutaneous delivery of CNTF and IGF-1 showed no clinical or survival benefits [77, 80-82]. However, more recent clinical trial infusing IGF-1 and BDNF intrathecally found modest beneficial effects in ALS patients with no severe adverse reactions [74-76, 79] which indicate that further studies should be design.

Transplantation of stem cells genetically engineered or otherwise induced to secrete such neurotrophic factors is another viable therapeutic approach. Applying gene therapy on stem cells prior to their transplantation to selectively combine the therapeutic effect of neurotrophic factor secretion and glutamate uptake might prove to provide the best survival chances of degeneration prone neurons, to ameliorate symptoms and reduce degeneration in ALS patients. In the case of fALS, a limited subset of ALS patients, the genetic bases of the disease is known and a more personalized treatment regime, such as RNA based silencing of the mutant SOD1 or other ALS related genes (e.g. TARDBP, ALS2 and ALS4 genes), should be considered.

A different therapeutic approach that may have the potential to modify the progression of ALS is a design of iron chelating multifunctional molecules. Indeed, preclinical studies with the novel multimodal iron chelating compound, M30, provide clear beneficial neuroprotective effects at the pre-symptomatic phase and at relatively advanced stage of the neurological dysfunctions. Further development of efficient neuroprotective drugs for early treatment along with early diagnostic of ALS patients is significant, since up-to-date almost all ALS patients are diagnosed after symptom onset. In view of the neuritogenic effect of M30 and its regulation of neurotrophic factors in motoneuron cells, it is possible that in vivo pro-survival effect of M30 is mediated through the regeneration process of motor nerves, inducing neuro-differentiation and sprouting of axons, leading to reinnervation of muscle fibers. Getting insight the molecular mechanism of the drug will assist in the translation of its protective effect from animal preclinical studies into human ALS. Since the process of motoneuron degeneration in ALS is complex and multifactorial, future studies should consider the use of multifunctional iron chelating drugs, such as M30 and HLA20, alone or in combination with other compounds. These compounds should be directed against distinct pathological mechanisms (e.g. anti-glutamergic drug, riluzole) and non- pharmaceutical approaches (e.g. highly energetic diet, moderated exercises) in other models of motoneuron degeneration, to develop the optimal neuroprotective treatment for ALS. The implication of multifunctional drug or "cocktail" therapies for ALS, together with a pathology-specific and patient-specific manner, may provide efficient tools against the significant heterogeneity at the molecular level and the population of ALS patients, to make progress in overcoming this disease.

Preclinical neuroprotective studies are planned with the intent of designing personalized medicine in which clinicians can tailor therapies to maximize benefit and minimize risk. Taken together, the therapeutic approaches outlined in this review, including multifunctional molecules, gene therapy and stem cell-based therapies could possibly form a beacon of hope for those patients suffering from ALS.

Acknowledgments The authors gratefully acknowledged the support of The Israeli ALS Research Association (Haifa, Israel) and the Technion-Research and Development and Rappaport Family Research Institute, Technion-Israel Institute of Technology (Haifa, Israel). The work was also supported, in part, by the Norma and Alan Aufzein Chair for Parkinson's Disease Research and the Devora Eleonora Kirshman Fund for Research of Parkinson`s Disease, Tel Aviv University.

\section{References}

1. Cronin S, Berger S, Ding J, Schymick JC, Washecka N, Hernandez DG, et al. A genome-wide association study of sporadic ALS in a homogenous Irish population. Hum Mol Genet. 2008;17:768-74.

2. Wijesekera LC, Leigh PN. Amyotrophic lateral sclerosis. Orphanet J Rare Dis. 2009;4:1-22.

3. Gonzalez de Aguilar JL, Echaniz-Laguna A, Fergani A, Rene F, Meininger V, Loeffler JP, et al. Amyotrophic lateral sclerosis: all roads lead to Rome. J Neurochem. 2007;101:1153-60.

4. Santillo AF, Skoglund L, Lindau M, Eeg-Olofsson KE, Tovi M, Engler $\mathrm{H}$, et al. Frontotemporal dementia-amyotrophic lateral sclerosis complex is simulated by neurodegeneration with brain iron accumulation. Alzheimer Dis Assoc Disord. 2009;23:298-300.

5. Cozzolino M, Ferri A, Carri MT. Amyotrophic lateral sclerosis: from current developments in the laboratory to clinical implications. Antioxid Redox Signal. 2008;10:405-43.

6. Valdmanis PN, Daoud H, Dion PA, Rouleau GA. Recent advances in the genetics of amyotrophic lateral sclerosis. Curr Neurol Neurosci Rep. 2009;9:198-205.

7. Strong MJ, Gordon PH. Primary lateral sclerosis, hereditary spastic paraplegia and amyotrophic lateral sclerosis: discrete entities or spectrum? Amyotroph Lateral Scler Other Mot Neuron Disord. 2005;6:8-16.

8. Valdmanis PN, Rouleau GA. Genetics of familial amyotrophic lateral sclerosis. Neurology. 2008;70:144-52.

9. Turner BJ, Talbot K. Transgenics, toxicity and therapeutics in rodent models of mutant SOD1-mediated familial ALS. Prog Neurobiol. 2008;85:94-134.

10. Beghi E, Mennini T, Bendotti C, Bigini P, Logroscino G, Chio A, et al. The heterogeneity of amyotrophic lateral sclerosis: a possible explanation of treatment failure. Curr Med Chem. 2007;14:3185-200. 
11. Brooks BR. Managing amyotrophic lateral sclerosis: slowing disease progression and improving patient quality of life. Ann Neurol. 2009;65 Suppl 1:S17-23.

12. Pioro EP. Antioxidant therapy in ALS. Amyotroph Lateral Scler Other Motor Neuron Disord. 2000;1 Suppl 4: 5-12; discussion $13-15$

13. Orrell RW, Lane RJ, Ross M. Antioxidant treatment for amyotrophic lateral sclerosis / motor neuron disease. Cochrane Database Syst Rev; The Cochrane Collaboration; Published by JohnWiley \& Sons, Ltd.; 2007. Issue 1.

14. Van Den Bosch L, Tilkin P, Lemmens G, Robberecht W. Minocycline delays disease onset and mortality in a transgenic model of ALS. NeuroReport. 2002;13:1067-70.

15. Gordon PH, Moore DH, Miller RG, Florence JM, Verheijde JL, Doorish C, et al. Efficacy of minocycline in patients with amyotrophic lateral sclerosis: a phase III randomised trial. Lancet Neurol. 2007;6:1045-53.

16. Miller RG, Mitchell JD, Lyon M, Moore DH. Riluzole for amyotrophic lateral sclerosis (ALS)/motor neuron disease (MND). Cochrane Database Syst Rev; The Cochrane Collaboration; Published by JohnWiley \& Sons; 2007. Ltd. Issue 1.

17. Nefussy B, Drory VE. Moving toward a predictive and personalized clinical approach in amyotrophic lateral sclerosis: novel developments and future directions in diagnosis, genetics, pathogenesis and therapies. EPMA-J. 2010. doi:10.1007/s13167010-0027-0.

18. Urushitani M, Ezzi SA, Julien JP. Therapeutic effects of immunization with mutant superoxide dismutase in mice models of amyotrophic lateral sclerosis. Proc Natl Acad Sci U S A. 2007;104:2495-500.

19. Imon Y, Yamaguchi S, Yamamura Y, Tsuji S, Kajima T, Ito K, et al. Low intensity areas observed on T2-weighted magnetic resonance imaging of the cerebral cortex in various neurological diseases. J Neurol Sci. 1995;134(Suppl):27-32.

20. Oba H, Araki T, Ohtomo K, Monzawa S, Uchiyama G, Koizumi $\mathrm{K}$, et al. Amyotrophic lateral sclerosis: T2 shortening in motor cortex at MR imaging. Radiology. 1993;189:843-6.

21. Sutedja NA, Sinke RJ, Van Vught PW, Van der Linden MW, Wokke JH, Van Duijn CM, et al. The association between H63D mutations in HFE and amyotrophic lateral sclerosis in a Dutch population. Arch Neurol. 2007;64:63-7.

22. Wang XS, Lee S, Simmons Z, Boyer P, Scott K, Liu W, et al. Increased incidence of the Hfe mutation in amyotrophic lateral sclerosis and related cellular consequences. J Neurol Sci. 2004;227:27-33.

23. Danzeisen R, Achsel T, Bederke U, Cozzolino M, Crosio C, Ferri A, et al. Superoxide dismutase 1 modulates expression of transferrin receptor. J Biol Inorg Chem. 2006;11:489-98.

24. Mizuno Y, Amari M, Takatama M, Aizawa H, Mihara B, Okamoto K. Transferrin localizes in Bunina bodies in amyotrophic lateral sclerosis. Acta Neuropathol. 2006;112:597603.

25. Pantopoulos K. Iron metabolism and the IRE/IRP regulatory system: an update. Ann N Y Acad Sci. 2004;1012:1-13.

26. Jeong SY, Rathore KI, Schulz K, Ponka P, Arosio P, David S. Dysregulation of iron homeostasis in the CNS contributes to disease progression in a mouse model of amyotrophic lateral sclerosis. J Neurosci. 2009;29:610-9.

27. Wu AS, Kiaei M, Aguirre N, Crow JP, Calingasan NY, Browne $\mathrm{SE}$, et al. Iron porphyrin treatment extends survival in a transgenic animal model of amyotrophic lateral sclerosis. J Neurochem. 2003;85:142-50.

28. Zheng H, Youdim MB, Weiner LM, Fridkin M. Novel potential neuroprotective agents with both iron chelating and amino acid-based derivatives targeting central nervous system neurons. Biochem Pharmacol. 2005;70:1642-52.
29. Zheng H, Youdim MB, Weiner LM, Fridkin M. Synthesis and evaluation of peptidic metal chelators for neuroprotection in neurodegenerative diseases. J Pept Res. 2005;66:190-203.

30. Gal S, Zheng H, Fridkin M, Youdim MB. Restoration of nigrostriatal dopamine neurons in post-MPTP treatment by the novel multifunctional brain-permeable iron chelator-monoamine oxidase inhibitor drug, M30. Neurotox Res. 2010;17:15-27.

31. Gal S, Zheng H, Fridkin M, Youdim MB. Novel multifunctional neuroprotective iron chelator-monoamine oxidase inhibitor drugs for neurodegenerative diseases. In vivo selective brain monoamine oxidase inhibition and prevention of MPTP-induced striatal dopamine depletion. J Neurochem. 2005;95:79-88.

32. Zheng H, Gal S, Weiner LM, Bar-Am O, Warshawsky A, Fridkin $\mathrm{M}$, et al. Novel multifunctional neuroprotective iron chelator-monoamine oxidase inhibitor drugs for neurodegenerative diseases: in vitro studies on antioxidant activity, prevention of lipid peroxide formation and monoamine oxidase inhibition. J Neurochem. 2005;95:68-78.

33. Avramovich-Tirosh Y, Amit T, Bar-Am O, Zheng H, Fridkin M, Youdim MB. Therapeutic targets and potential of the novel brain- permeable multifunctional iron chelator-monoamine oxidase inhbitor drug, M-30, for the treatment of Alzheimer's disease. J Neurochem. 2007;100:490-502.

34. Avramovich-Tirosh Y, Bar-Am O, Amit T, Youdim MB, Weinreb O. Up-regulation of Hypoxia-Inducible Factor (HIF) -1alpha and HIFTarget Genes in Cortical Neurons by the Novel Multifunctional Iron Chelator Anti-Alzheimer Drug, M30. Curr Alzheimer Res. 2010;7:300-6.

35. Avramovich-Tirosh Y, Reznichenko L, Mit T, Zheng H, Fridkin M, Weinreb O, et al. Neurorescue Activity, APP Regulation and Amyloid-beta Peptide Reduction by Novel Multi-Functional Brain Permeable Iron- Chelating- Antioxidants, M-30 and Green Tea Polyphenol, EGCG. Curr Alzheimer Res. 2007;4:403-11.

36. Kupershmidt L, Weinreb O, Amit T, Mandel S, Carri MT, Youdim MB. Neuroprotective and neuritogenic activities of novel multimodal iron-chelating drugs in motor-neuron-like NSC-34 cells and transgenic mouse model of amyotrophic lateral sclerosis. FASEB J. 2009;23:3766-79.

37. Zhu W, Xie W, Pan T, Xu P, Fridkin M, Zheng $\mathrm{H}$, et al. Prevention and restoration of lactacystin-induced nigrostriatal dopamine neuron degeneration b. 2007.

38. Kriz J, Nguyen MD, Julien JP. Minocycline slows disease progression in a mouse model of amyotrophic lateral sclerosis. Neurobiol Dis. 2002;10:268-78.

39. Waibel S, Reuter A, Malessa S, Blaugrund E, Ludolph AC. Rasagiline alone and in combination with riluzole prolongs survival in an ALS mouse model. J Neurol. 2004;251:1080-4.

40. Youdim MB, Fridkin M, Zheng H. Bifunctional drug derivatives of MAO-B inhibitor rasagiline and iron chelator VK-28 as a more effective approach to treatment of brain ageing and ageing neurodegenerative diseases. Mech Ageing Dev. 2005;126:317-26.

41. Cassina P, Peluffo H, Pehar M, Martinez-Palma L, Ressia A, Beckman JS, et al. Peroxynitrite triggers a phenotypic transformation in spinal cord astrocytes that induces motor neuron apoptosis. J Neurosci Res. 2002;67:21-9.

42. Martin LJ. Transgenic mice with human mutant genes causing Parkinson's disease and amyotrophic lateral sclerosis provide common insight into mechanisms of motor neuron selective vulnerability to degeneration. Rev Neurosci. 2007;18:11536.

43. Bar-Am O, Weinreb O, Amit T, Youdim MB. Regulation of Bcl-2 family proteins, neurotrophic factors, and APP processing in the neurorescue activity of propargylamine. FASEB J. 2005;19:1899 901.

44. Bar-Am O, Yogev-Falach M, Amit T, Sagi Y, Youdim MBH. Regulation of protein kinase $\mathrm{C}$ by the anti-Parkinson drug, 
MAO-B inhibitor, rasagiline and its derivatives, in vivo. $\mathrm{J}$ Neurochem. 2004;89:1119-25.

45. Weinreb O, Bar-Am O, Amit T, Chillag-Talmor O, Youdim $\mathrm{MBH}$. Neuroprotection via pro-survival protein kinase $\mathrm{C}$ isoforms associated with Bcl-2 family members. FASEB J. 2004;18:1471-3.

46. Weinreb O, Amit T, Mandel S, Kupershmidt L, Youdim MB. Neuroprotective multifunctional iron chelators: from redoxsensitive process to novel therapeutic opportunities. Antioxid Redox Signal. 2010;13: doi:10.1089/ars2009.2929.

47. Siddiq A, Ayoub IA, Chavez JC, Aminova L, Shah S, LaManna JC, et al. Hypoxia-inducible factor prolyl 4-hydroxylase inhibition. A target for neuroprotection in the central nervous system J Biol Chem. 2005;280:41732-43.

48. Semenza GL. Expression of hypoxia-inducible factor 1: mechanisms and consequences. Biochem Pharmacol. 2000;59:47-53.

49. Semenza GL, Agani F, Feldser D, Iyer N, Kotch L, Laughner E, et al. Hypoxia, HIF-1, and the pathophysiology of common human diseases. Adv Exp Med Biol. 2000;475:123-30.

50. Almli LM, Hamrick SE, Koshy AA, Tauber MG, Ferriero DM. Multiple pathways of neuroprotection against oxidative stress and excitotoxic injury in immature primary hippocampal neurons. Brain Res Dev Brain Res. 2001;132:121-9.

51. Tolosa L, Mir M, Olmos G, Llado J. Vascular endothelial growth factor protects motoneurons from serum deprivation-induced cell death through phosphatidylinositol 3-kinase-mediated p38 mitogen-activated protein kinase inhibition. Neuroscience. 2009; 158:1348-55.

52. Lambrechts D, Storkebaum E, Morimoto M, Del-Favero J, Desmet F, Marklund SL, et al. VEGF is a modifier of amyotrophic lateral sclerosis in mice and humans and protects motoneurons against ischemic death. Nat Genet. 2003;34:38394.

53. Moreau C, Devos D, Brunaud-Danel V, Defebvre L, Perez T, Destee A, et al. Paradoxical response of VEGF expression to hypoxia in CSF of patients with ALS. J Neurol Neurosurg Psychiatry. 2006;77:255-7.

54. Van Den Bosch L, Storkebaum E, Vleminckx V, Moons L, Vanopdenbosch L, Scheveneels W, et al. Effects of vascular endothelial growth factor (VEGF) on motor neuron degeneration. Neurobiol Dis. 2004;17:21-8

55. Chen C, Pore N, Behrooz A, Ismail-Beigi F, Maity A. Regulation of glut1 mRNA by hypoxia-inducible factor-1. Interaction between H-ras and hypoxia. J Biol Chem. 2001;276:9519-25.

56. Semenza GL, Roth PH, Fang HM, Wang GL. Transcriptional regulation of genes encoding glycolytic enzymes by hypoxiainducible factor 1. J Biol Chem. 1994;269:23757-63.

57. Brand K. Aerobic glycolysis by proliferating cells: protection against oxidative stress at the expense of energy yield. J Bioenerg Biomembr. 1997;29:355-64.

58. Blancher C, Moore JW, Robertson N, Harris AL. Effects of ras and von Hippel-Lindau (VHL) gene mutations on hypoxia-inducible factor (HIF)-1alpha, HIF-2alpha, and vascular endothelial growth factor expression and their regulation by the phosphatidylinositol 3'-kinase/Akt signaling pathway. Cancer Res. 2001;61:7349-55.

59. Jiang BH, Jiang $G$, Zheng JZ, Lu Z, Hunter T, Vogt PK. Phosphatidylinositol 3-kinase signaling controls levels of hypoxia-inducible factor 1. Cell Growth Differ. 2001;12:363-9.

60. Forde JE, Dale TC. Glycogen synthase kinase 3: a key regulator of cellular fate. Cell Mol Life Sci. 2007;64:1930-44.

61. Kulp KS, Green SL, Vulliet PR. Iron deprivation inhibits cyclindependent kinase activity and decreases cyclin $\mathrm{D} / \mathrm{CDK} 4$ protein levels in asynchronous MDA-MB-453 human breast cancer cells. Exp Cell Res. 1996;229:60-8.

62. Nurtjahja-Tjendraputra E, Fu D, Phang JM, Richardson DR. Iron chelation regulates cyclin D1 expression via the proteasome: a link to iron deficiency-mediated growth suppression. Blood. 2007;109:4045-54.

63. Amit T, Avramovich-Tirosh Y, Youdim MB, Mandel S. Targeting multiple Alzheimer's disease etiologies with multimodal neuroprotective and neurorestorative iron chelators. FASEB J. 2008;22:1296-305.

64. Buck CR, Seburn KL, Cope TC. Neurotrophin expression by spinal motoneurons in adult and developing rats. J Comp Neurol. 2000;416:309-18.

65. Namiki J, Kojima A, Tator CH. Effect of brain-derived neurotrophic factor, nerve growth factor, and neurotrophin-3 on functional recovery and regeneration after spinal cord injury in adult rats. J Neurotrauma. 2000;17:1219-31.

66. Qin DX, Zou XL, Luo W, Zhang W, Zhang HT, Li XL, et al. Expression of some neurotrophins in the spinal motoneurons after cord hemisection in adult rats. Neurosci Lett. 2006;410:222-7.

67. Bendotti C, Carri MT. Lessons from models of SOD1-linked familial ALS. Trends Mol Med. 2004;10:393-400.

68. Arai T, Hasegawa M, Akiyama H, Ikeda K, Nonaka T, Mori H, et al. TDP-43 is a component of ubiquitin-positive tau-negative inclusions in frontotemporal lobar degeneration and amyotrophic lateral sclerosis. Biochem Biophys Res Commun. 2006;351:602-11.

69. Sumi H, Kato S, Mochimaru Y, Fujimura H, Etoh M, Sakoda S. Nuclear TAR DNA binding protein 43 expression in spinal cord neurons correlates with the clinical course in amyotrophic lateral sclerosis. J Neuropathol Exp Neurol. 2009;68:37-47.

70. Weinreb O, Amit T, Mandel S, Youdim MB. Neuroprotective molecular mechanisms of (-)-epigallocatechin-3-gallate: a reflective outcome of its antioxidant, iron chelating and neuritogenic properties. Genes Nutr. 2009;4:283-96.

71. Koh SH, Kwon H, Kim KS, Kim J, Kim MH, Yu HJ, et al. Epigallocatechin gallate prevents oxidative-stress-induced death of mutant $\mathrm{Cu} / \mathrm{Zn}$-superoxide dismutase (G93A) motoneuron cells by alteration of cell survival and death signals. Toxicology. 2004;202:213-25.

72. Koh SH, Lee SM, Kim HY, Lee KY, Lee YJ, Kim HT, et al. The effect of epigallocatechin gallate on suppressing disease progression of ALS model mice. Neurosci Lett. 2006;395:103-7.

73. Xu Z, Chen S, Li X, Luo G, Li L, Le W. Neuroprotective effects of (-)-epigallocatechin-3-gallate in a transgenic mouse model of amyotrophic lateral sclerosis. Neurochem Res. 2006;31:1263-9.

74. Beck M, Flachenecker P, Magnus T, Giess R, Reiners K, Toyka $\mathrm{KV}$, et al. Autonomic dysfunction in ALS: a preliminary study on the effects of intrathecal BDNF. Amyotroph Lateral Scler Other Mot Neuron Disord. 2005;6:100-3.

75. Ochs G, Penn RD, York M, Giess R, Beck M, Tonn J, et al. A phase I/II trial of recombinant methionyl human brain derived neurotrophic factor administered by intrathecal infusion to patients with amyotrophic lateral sclerosis. Amyotroph Lateral Scler Other Mot Neuron Disord. 2000;1:201-6.

76. The BDNF Study Group (Phase III). A controlled trial of recombinant methionyl human BDNF in ALS. Neurology. 1999;52:1427-33.

77. Borasio GD, Robberecht W, Leigh PN, Emile J, Guiloff RJ, Jerusalem F, et al. A placebo-controlled trial of insulin-like growth factor-I in amyotrophic lateral sclerosis. European ALS/ IGF-I Study Group. Neurology. 1998;51:583-6.

78. Lai EC, Felice KJ, Festoff BW, Gawel MJ, Gelinas DF, Kratz R, et al. Effect of recombinant human insulin-like growth factor-I on progression of ALS. A placebo-controlled study. The North America ALS/IGF-I Study Group. Neurology. 1997;49:1621-30.

79. Nagano I, Shiote M, Murakami T, Kamada H, Hamakawa Y, Matsubara E, et al. Beneficial effects of intrathecal IGF-1 administration in patients with amyotrophic lateral sclerosis. Neurol Res. 2005;27:768-72. 
80. ALS CNTF Treatment Study Group. A double-blind placebocontrolled clinical trial of subcutaneous recombinant human ciliary neurotrophic factor (rHCNTF) in amyotrophic lateral sclerosis. Neurology. 1996;46:1244-9.

81. Miller RG, Bryan WW, Dietz MA, Munsat TL, Petajan JH, Smith SA, et al. Toxicity and tolerability of recombinant human ciliary neurotrophic factor in patients with amyotrophic lateral sclerosis. Neurology. 1996;47:1329-31.

82. Miller RG, Petajan JH, Bryan WW, Armon C, Barohn RJ, Goodpasture JC, et al. A placebo-controlled trial of recombinant human ciliary neurotrophic (rhCNTF) factor in amyotrophic lateral sclerosis. rhCNTF ALS Study Group. Ann Neurol. 1996;39:256-60.

83. Mazzini L, Ferrero I, Luparello V, Rustichelli D, Gunetti M, Mareschi K, et al. Mesenchymal stem cell transplantation in amyotrophic lateral sclerosis: A Phase I clinical trial. Exp Neurol. 2009;223:229-37.

84. Mazzini L, Mareschi K, Ferrero I, Vassallo E, Oliveri G, Nasuelli $\mathrm{N}$, et al. Stem cell treatment in Amyotrophic Lateral Sclerosis. J Neurol Sci. 2008;265:78-83.

85. Appel SH, Engelhardt JI, Henkel JS, Siklos L, Beers DR, Yen AA, et al. Hematopoietic stem cell transplantation in patients with sporadic amyotrophic lateral sclerosis. Neurology. 2008;71:1326-34.

86. Aebischer P, Pochon NA, Heyd B, Deglon N, Joseph JM, Zurn $\mathrm{AD}$, et al. Gene therapy for amyotrophic lateral sclerosis (ALS) using a polymer encapsulated xenogenic cell line engineered to secrete hCNTF. Hum Gene Ther. 1996;7:851-60.

87. Aebischer P, Schluep M, Déglon N, Joseph JM, Hirt L, Heyd B, et al. Intrathecal delivery of CNTF using encapsulated genetically modified xenogeneic cells in amyotrophic lateral sclerosis patients. Nat Med. 1996;2:696-9.

88. Zurn AD, Henry H, Schluep M, Aubert V, Winkel L, Eilers B, et al. Evaluation of an intrathecal immune response in amyotrophic lateral sclerosis patients implanted with encapsulated genetically engineered xenogeneic cells. Cell Transplant. 2000;9:471-84.

89. Dodge JC, Haidet AM, Yang W, Passini MA, Hester M, Clarke $\mathrm{J}$, et al. Delivery of AAV-IGF-1 to the CNS extends survival in ALS mice through modification of aberrant glial cell activity. Mol Ther. 2008;16:1056-64.

90. Kaspar BK, Llado J, Sherkat N, Rothstein JD, Gage FH. Retrograde viral delivery of IGF-1 prolongs survival in a mouse ALS model. Science. 2003;301:839-42.

91. Franz CK, Federici T, Yang J, Backus C, Oh SS, Teng Q, et al. Intraspinal cord delivery of IGF-I mediated by adeno-associated virus 2 is neuroprotective in a rat model of familial ALS. Neurobiol Dis. 2009;33:473-81.

92. Lepore AC, Haenggeli C, Gasmi M, Bishop KM, Bartus RT, Maragakis NJ, et al. Intraparenchymal spinal cord delivery of adeno-associated virus IGF-1 is protective in the SOD1G93A model of ALS. Brain Res. 2007;1185:256-65.

93. Wang LJ, Lu YY, Muramatsu S, Ikeguchi K, Fujimoto K, Okada $\mathrm{T}$, et al. Neuroprotective effects of glial cell line-derived neurotrophic factor mediated by an adeno-associated virus vector in a transgenic animal model of amyotrophic lateral sclerosis. $\mathrm{J}$ Neurosci. 2002;22:6920-8

94. Azzouz M, Hottinger A, Paterna JC, Zurn AD, Aebischer P, Büeler $\mathrm{H}$. Increased motoneuron survival and improved neuromuscular function in transgenic ALS mice after intraspinal injection of an adeno-associated virus encoding Bcl-2. Hum Mol Genet. 2000;9:803-11.

95. Guillot S, Azzouz M, Déglon N, Zurn A, Aebischer P. Local GDNF expression mediated by lentiviral vector protects facial nerve motoneurons but not spinal motoneurons in SOD1(G93A) transgenic mice. Neurobiol Dis. 2004;16:139-49.
96. Hottinger AF, Azzouz M, Déglon N, Aebischer P, Zurn AD. Complete and long-term rescue of lesioned adult motoneurons by lentiviral-mediated expression of glial cell line-derived neurotrophic factor in the facial nucleus. J Neurosci. 2000;20:5587-93.

97. Azzouz M, Ralph GS, Storkebaum E, Walmsley LE, Mitrophanous KA, Kingsman SM, et al. VEGF delivery with retrogradely transported lentivector prolongs survival in a mouse ALS model. Nature. 2004;429:413-7.

98. Moreno-Igoa M, Calvo AC, Penas C, Manzano R, Oliván S, Muñoz $\mathrm{MJ}$, et al. Fragment $\mathrm{C}$ of tetanus toxin, more than a carrier. Novel perspectives in non-viral ALS gene therapy. J Mol Med. 2010;88:297-308.

99. Chian RJ, Li J, Ay I, Celia SA, Kashi BB, Tamrazian E, et al. IGF-1:tetanus toxin fragment $C$ fusion protein improves delivery of IGF-1 to spinal cord but fails to prolong survival of ALS mice. Brain Res. 2009;1287:1-19.

100. Ciriza J, Moreno-Igoa M, Calvo AC, Yague G, Palacio J, MianaMena FJ, et al. A genetic fusion GDNF-C fragment of tetanus toxin prolongs survival in a symptomatic mouse ALS model. Restor Neurol Neurosci. 2008;26:459-65.

101. Xu L, Ryugo DK, Pongstaporn T, Johe K, Koliatsos VE. Human neural stem cell grafts in the spinal cord of SOD1 transgenic rats: differentiation and structural integration into the segmental motor circuitry. J Comp Neurol. 2009;514:297-309.

102. Xu L, Yan J, Chen D, Welsh AM, Hazel T, Johe K, et al. Human neural stem cell grafts ameliorate motor neuron disease in SOD-1 transgenic rats. Transplantation. 2006;82:865-75.

103. Lepore AC, Rauck B, Dejea C, Pardo AC, Rao MS, Rothstein $\mathrm{JD}$, et al. Focal transplantation-based astrocyte replacement is neuroprotective in a model of motor neuron disease. Nat Neurosci. 2008;11:1294-301.

104. Maragakis NJ, Rao MS, Llado J, Wong V, Xue H, Pardo A, et al. Glial restricted precursors protect against chronic glutamate neurotoxicity of motor neurons in vitro. Glia. 2005;50:145-59.

105. Boucherie C, Schäfer S, Lavand'homme P, Maloteaux JM, Hermans E. Chimerization of astroglial population in the lumbar spinal cord after mesenchymal stem cell transplantation prolongs survival in a rat model of amyotrophic lateral sclerosis. J Neurosci Res. 2009;87:2034-46.

106. Kim H, Kim HY, Choi MR, Hwang S, Nam KH, Kim HC, et al. Dose-dependent efficacy of ALS-human mesenchymal stem cells transplantation into cisterna magna in SOD1-G93A ALS mice. Neurosci Lett. 2010;468:190-4.

107. Vercelli A, Mereuta OM, Garbossa D, Muraca G, Mareschi K, Rustichelli D, et al. Human mesenchymal stem cell transplantation extends survival, improves motor performance and decreases neuroinflammation in mouse model of amyotrophic lateral sclerosis. Neurobiol Dis. 2008;31:395-405.

108. Zhao CP, Zhang C, Zhou SN, Xie YM, Wang YH, Huang H, et al. Human mesenchymal stromal cells ameliorate the phenotype of SOD1-G93A ALS mice. Cytotherapy. 2007;9:414-26.

109. Beers DR, Henkel JS, Xiao Q, Zhao W, Wang J, Yen AA, et al. Wild-type microglia extend survival in PU.1 knockout mice with familial amyotrophic lateral sclerosis. Proc Natl Acad Sci U S A. 2006;103:16021-6.

110. Ohnishi S, Ito H, Suzuki Y, Adachi Y, Wate R, Zhang J, et al. Intra-bone marrow-bone marrow transplantation slows disease progression and prolongs survival in G93A mutant SOD1 transgenic mice, an animal model mouse for amyotrophic lateral sclerosis. Brain Res. 2009;1296:216-24.

111. Ende N, Weinstein F, Chen R, Ende M. Human umbilical cord blood effect on sod mice (amyotrophic lateral sclerosis). Life Sci. 2000;67:53-9.

112. Klein SM, Behrstock S, McHugh J, Hoffmann K, Wallace K, Suzuki M, et al. GDNF delivery using human neural 
progenitor cells in a rat model of ALS. Hum Gene Ther. 2005;16:509-21.

113. Park S, Kim HT, Yun S, Kim IS, Lee J, Lee IS, et al. Growth factor-expressing human neural progenitor cell grafts protect motor neurons but do not ameliorate motor performance and survival in ALS mice. Exp Mol Med. 2009;41:487-500.

114. Suzuki M, McHugh J, Tork C, Shelley B, Klein SM, Aebischer $\mathrm{P}$, et al. GDNF secreting human neural progenitor cells protect dying motor neurons, but not their projection to muscle, in a rat model of familial ALS. PLoS ONE. 2007;2:e689.

115. Suzuki M, McHugh J, Tork C, Shelley B, Hayes A, Bellantuono I, et al. Direct muscle delivery of GDNF with human mesenchymal stem cells improves motor neuron survival and function in a rat model of familial ALS. Mol Ther. 2008;16:2002-10.

116. Hwang DH, Lee HJ, Park IH, Seok JI, Kim BG, Joo IS, et al. Intrathecal transplantation of human neural stem cells overexpressing VEGF provide behavioral improvement, disease onset delay and survival extension in transgenic ALS mice. Gene Ther. 2009;16:1234-44.

117. Alisky JM, Davidson BL. Gene therapy for amyotrophic lateral sclerosis and other motor neuron diseases. Hum Gene Ther. 2000;11:2315-29.

118. Berns KI. Parvovirus replication. Microbiol Rev. 1990;54:316-29.

119. Lu YY, Wang LJ, Muramatsu S, Ikeguchi K, Fujimoto K, Okada $\mathrm{T}$, et al. Intramuscular injection of AAV-GDNF results in sustained expression of transgenic GDNF, and its delivery to spinal motoneurons by retrograde transport. Neurosci Res. 2003;45:33-40.

120. Cockrell AS, Kafri T. Gene delivery by lentivirus vectors. Mol Biotechnol. 2007;36:184-204.

121. Lewis P, Hensel M, Emerman M. Human immunodeficiency virus infection of cells arrested in the cell cycle. EMBO J. 1992;11:3053-8.

122. Naldini L, Blömer U, Gallay P, Ory D, Mulligan R, Gage FH, et al. In vivo gene delivery and stable transduction of nondividing cells by a lentiviral vector. Science. 1996;272:263-7.

123. Azzouz M. Gene Therapy for ALS: progress and prospects. Biochim Biophys Acta. 2006;1762:1122-7.

124. Cronin J, Zhang XY, Reiser J. Altering the tropism of lentiviral vectors through pseudotyping. Curr Gene Ther. 2005;5:387-98.

125. Dimos JT, Rodolfa KT, Niakan KK, Weisenthal LM, Mitsumoto $\mathrm{H}$, Chung $\mathrm{W}$, et al. Induced pluripotent stem cells generated from patients with ALS can be differentiated into motor neurons. Science. 2008;321:1218-21.

126. Harper JM, Krishnan C, Darman JS, Deshpande DM, Peck S, Shats I, et al. Axonal growth of embryonic stem cell-derived motoneurons in vitro and in motoneuron-injured adult rats. Proc Natl Acad Sci U S A. 2004;101:7123-8.

127. López-González R, Kunckles P, Velasco I. Transient recovery in a rat model of familial amyotrophic lateral sclerosis after transplantation of motor neurons derived from mouse embryonic stem cells. Cell Transplant. 2009;18:1171-81.

128. Garbuzova-Davis S, Willing AE, Milliken M, Saporta S, Zigova T, Cahill DW, et al. Positive effect of transplantation of hNT neurons (NTera 2/D1 cell-line) in a model of familial amyotrophic lateral sclerosis. Exp Neurol. 2002;174:169-80.

129. Willing AE, Garbuzova-Davis S, Saporta S, Milliken M, Cahill DW, Sanberg PR. hNT neurons delay onset of motor deficits in a model of amyotrophic lateral sclerosis. Brain Res Bull. 2001;56:525-30.

130. Sharma HS. Interaction between amino acid neurotransmitters and opioid receptors in hyperthermia-induced brain pathology. Prog Brain Res. 2007;162:295-317.

131. Luo Y, Xue H, Pardo AC, Mattson MP, Rao MS, Maragakis NJ. Impaired SDF1/CXCR4 signaling in glial progenitors derived from SOD1(G93A) mice. J Neurosci Res. 2007;85:242232 .

132. Nagai M, Re DB, Nagata $T$, Chalazonitis A, Jessell TM, Wichterle $\mathrm{H}$, et al. Astrocytes expressing ALS-linked mutated SOD1 release factors selectively toxic to motor neurons. Nat Neurosci. 2007;10:615-22.

133. Pramatarova A, Laganière $\mathrm{J}$, Roussel $\mathrm{J}$, Brisebois $\mathrm{K}$, Rouleau GA. Neuron-specific expression of mutant superoxide dismutase 1 in transgenic mice does not lead to motor impairment. J Neurosci. 2001;21:3369-74.

134. Yamanaka K, Chun SJ, Boillee S, Fujimori-Tonou N, Yamashita $\mathrm{H}$, Gutmann DH, et al. Astrocytes as determinants of disease progression in inherited amyotrophic lateral sclerosis. Nat Neurosci. 2008;11:251-3.

135. Maragakis NJ, Rothstein JD. Mechanisms of Disease: astrocytes in neurodegenerative disease. Nat Clin Pract Neurol. 2006;2:679-89.

136. Bahat-Stroomza M, Barhum Y, Levy YS, Karpov O, Bulvik S, Melamed $\mathrm{E}$, et al. Induction of adult human bone marrow mesenchymal stromal cells into functional astrocyte-like cells: potential for restorative treatment in Parkinson's disease. J Mol Neurosci. 2009;39:199-210.

137. Sanchez-Ramos J, Song S, Cardozo-Pelaez F, Hazzi C, Stedeford $\mathrm{T}$, Willing A, et al. Adult bone marrow stromal cells differentiate into neural cells in vitro. Exp Neurol. 2000;164:247-56.

138. Suzuki H, Taguchi T, Tanaka H, Kataoka H, Li Z, Muramatsu K, et al. Neurospheres induced from bone marrow stromal cells are multipotent for differentiation into neuron, astrocyte, and oligodendrocyte phenotypes. Biochem Biophys Res Commun. 2004;322:918-22.

139. François S, Bensidhoum M, Mouiseddine M, Mazurier C, Allenet B, Semont A, et al. Local irradiation not only induces homing of human mesenchymal stem cells at exposed sites but promotes their widespread engraftment to multiple organs: a study of their quantitative distribution after irradiation damage. Stem Cells. 2006;24:1020-9.

140. Battiwalla M, Hematti P. Mesenchymal stem cells in hematopoietic stem cell transplantation. Cytotherapy. 2009;11:503-15.

141. Bossolasco P, Cova L, Calzarossa C, Servida F, Mencacci NE, Onida F, et al. Metalloproteinase alterations in the bone marrow of ALS patients. J Mol Med. 2010. doi:10.1007/s00109-0090584-7.

142. Cho GW, Noh MY, Kim HY, Koh SH, Kim KS, Kim SH. Bone marrow derived stromal cells from amyotrophic lateral sclerosis patients have diminished stem cell capacity. Stem Cells Dev. 2009. doi:10.1089/scd.2009.0453.

143. Demestre M, Pullen A, Orrell RW, Orth M. ALS-IgG-induced selective motor neurone apoptosis in rat mixed primary spinal cord cultures. J Neurochem. 2005;94:268-75.

144. Engelhardt JI, Soós J, Obál I, Vigh L, Siklós L. Subcellular localization of $\operatorname{IgG}$ from the sera of ALS patients in the nervous system. Acta Neurol Scand. 2005;112:126-33.

145. Hall ED, Oostveen JA, Gurney ME. Relationship of microglial and astrocytic activation to disease onset and progression in a transgenic model of familial ALS. Glia. 1998;23:249-56.

146. Henkel JS, Beers DR, Zhao W, Appel SH. Microglia in ALS: the good, the bad, and the resting. J Neuroimmune Pharmacol. 2009;4:389-98.

147. Sargsyan SA, Monk PN, Shaw PJ. Microglia as potential contributors to motor neuron injury in amyotrophic lateral sclerosis. Glia. 2005;51:241-53.

148. Obál I, Jakab JS, Siklós L, Engelhardt JI. Recruitment of activated microglia cells in the spinal cord of mice by ALS IgG. NeuroReport. 2001;12:2449-52.

149. Pullen AH, Demestre M, Howard RS, Orrell RW. Passive transfer of purified $\mathrm{IgG}$ from patients with amyotrophic lateral sclerosis to 
mice results in degeneration of motor neurons accompanied by Ca2+ enhancement. Acta Neuropathol. 2004;107:35-46.

150. de Hemptinne I, Vermeiren C, Maloteaux JM, Hermans E. Induction of glial glutamate transporters in adult mesenchymal stem cells. J Neurochem. 2004;91:155-66.

151. Pineda JR, Rubio N, Akerud P, Urbán N, Badimon L, Arenas E, et al. Neuroprotection by GDNF-secreting stem cells in a Huntington's disease model: optical neuroimage tracking of brain-grafted cells. Gene Ther. 2007;14:118-28.

152. Cunningham LA, Su C. Astrocyte delivery of glial cell linederived neurotrophic factor in a mouse model of Parkinson's disease. Exp Neurol. 2002;174:230-42.

153. Patel NK, Bunnage M, Plaha P, Svendsen CN, Heywood P, Gill SS. Intraputamenal infusion of glial cell line-derived neurotrophic factor in PD: a two-year outcome study. Ann Neurol. 2005;57:298 302.

154. Slevin JT, Gash DM, Smith CD, Gerhardt GA, Kryscio R, Chebrolu $\mathrm{H}$, et al. Unilateral intraputamenal glial cell linederived neurotrophic factor in patients with Parkinson disease: response to 1 year of treatment and 1 year of withdrawal. J Neurosurg. 2007;106:614-20.

155. Li W, Brakefield D, Pan Y, Hunter D, Myckatyn TM, Parsadanian A. Muscle-derived but not centrally derived transgene GDNF is neuroprotective in G93A-SOD1 mouse model of ALS. Exp Neurol. 2007;203:457-71.

156. Oosthuyse B, Moons L, Storkebaum E, Beck H, Nuyens D, Brusselmans K, et al. Deletion of the hypoxia-response element in the vascular endothelial growth factor promoter causes motor neuron degeneration. Nat Genet. 2001;28:131-8.

157. Wang Y, Mao XO, Xie L, Banwait S, Marti HH, Greenberg DA, et al. Vascular endothelial growth factor overexpression delays neurodegeneration and prolongs survival in amyotrophic lateral sclerosis mice. J Neurosci. 2007;27:304-7.

158. Lambrechts D, Carmeliet P. VEGF at the neurovascular interface: therapeutic implications for motor neuron disease. Biochim Biophys Acta. 2006;1762:1109-21.

159. Rizvanov AA, Kiyasov AP, Gaziziov IM, Yilmaz TS, Kaligin MS, Andreeva DI, et al. Human umbilical cord blood cells transfected with VEGF and L(1)CAM do not differentiate into neurons but transform into vascular endothelial cells and secrete neuro-trophic factors to support neuro-genesis-a novel approach in stem cell therapy. Neurochem Int. 2008;53:38994.

160. Zheng C, Nennesmo I, Fadeel B, Henter JI. Vascular endothelial growth factor prolongs survival in a transgenic mouse model of ALS. Ann Neurol. 2004;56:564-7.

161. Bogaert E, Van Damme P, Poesen K, Dhondt J, Hersmus N, Kiraly $\mathrm{D}$, et al. VEGF protects motor neurons against excitotoxicity by upregulation of GluR2. Neurobiol Aging. 2009. doi:10.1016/j. neurobiolaging.2008.12.007.

162. Tolosa L, Mir M, Asensio VJ, Olmos G, Lladó J. Vascular endothelial growth factor protects spinal cord motoneurons against glutamate-induced excitotoxicity via phosphatidylinositol 3-kinase. J Neurochem. 2008;105:1080-90.

163. Vergani L, Finco C, Di Giulio AM, Muller EE, Gorio A. Effects of low doses of glycosaminoglycans and insulin-like growth factor-I on motor neuron disease in wobbler mouse. Neurosci Lett. 1997;228:41-4.

164. Vergani L, Losa M, Lesma E, Di Giulio AM, Torsello A, Muller EE, et al. Glycosaminoglycans boost insulin-like growth factor-Ipromoted neuroprotection: blockade of motor neuron death in the wobbler mouse. Neuroscience. 1999;93:565-72.

165. Sorenson EJ, Windbank AJ, Mandrekar JN, Bamlet WR, Appel $\mathrm{SH}$, Armon C, et al. Subcutaneous IGF-1 is not beneficial in 2-year ALS trial. Neurology. 2008;71:1770-5.
166. Danbolt NC, Chaudhry FA, Dehnes Y, Lehre KP, Levy LM, Ullensvang $\mathrm{K}$, et al. Properties and localization of glutamate transporters. Prog Brain Res. 1998;116:23-43.

167. Danbolt NC. Glutamate uptake. Prog Neurobiol. 2001;65:1-105.

168. Maragakis NJ, Rothstein JD. Glutamate transporters in neurologic disease. Arch Neurol. 2001;58:365-70.

169. Mattson MP. Glutamate and neurotrophic factors in neuronal plasticity and disease. Ann N Y Acad Sci. 2008;1144:97-112.

170. Molz S, Decker H, Dal-Cim T, Cremonez C, Cordova FM, Leal $\mathrm{RB}$, et al. Glutamate-induced toxicity in hippocampal slices involves apoptotic features and p38 MAPK signaling. Neurochem Res. 2008;33:27-36.

171. Lee Y, Park HW, Park SG, Cho S, Myung PK, Park BC, et al. Proteomic analysis of glutamate-induced toxicity in HT22 cells. Proteomics. 2007;7:185-93.

172. Sheldon AL, Robinson MB. The role of glutamate transporters in neurodegenerative diseases and potential opportunities for intervention. Neurochem Int. 2007;51:333-55.

173. Sonnewald U, Qu H, Aschner M. Pharmacology and toxicology of astrocyte-neuron glutamate transport and cycling. J Pharmacol Exp Ther. 2002;301:1-6.

174. Bendotti C, Tortarolo M, Suchak SK, Calvaresi N, Carvelli L, Bastone A, et al. Transgenic SOD1 G93A mice develop reduced GLT-1 in spinal cord without alterations in cerebrospinal fluid glutamate levels. J Neurochem. 2001;79:737-46.

175. Howland DS, Liu J, She Y, Goad B, Maragakis NJ, Kim B, et al. Focal loss of the glutamate transporter EAAT2 in a transgenic rat model of SOD1 mutant-mediated amyotrophic lateral sclerosis (ALS). Proc Natl Acad Sci U S A. 2002;99:1604-9.

176. Lin CL, Bristol LA, Jin L, Dykes-Hoberg M, Crawford T, Clawson $\mathrm{L}$, et al. Aberrant RNA processing in a neurodegenerative disease: the cause for absent EAAT2, a glutamate transporter, in amyotrophic lateral sclerosis. Neuron. 1998;20:589-602.

177. Meyer T, Fromm A, Münch C, Schwalenstöcker B, Fray AE, Ince PG, et al. The RNA of the glutamate transporter EAAT2 is variably spliced in amyotrophic lateral sclerosis and normal individuals. J Neurol Sci. 1999;170:45-50.

178. Rothstein JD, Van Kammen M, Levey AI, Martin LJ, Kuncl RW. Selective loss of glial glutamate transporter GLT-1 in amyotrophic lateral sclerosis. Ann Neurol. 1995;38:73-84.

179. Guo H, Lai L, Butchbach ME, Stockinger MP, Shan X, Bishop $\mathrm{GA}$, et al. Increased expression of the glial glutamate transporter EAAT2 modulates excitotoxicity and delays the onset but not the outcome of ALS in mice. Hum Mol Genet. 2003;12:2519-32.

180. Joseph D'Ercole A, Ye P. Expanding the mind: insulin-like growth factor I and brain development. Endocrinology. 2008;149:5958-62.

181. Lunn JS, Sakowski SA, Kim B, Rosenberg AA, Feldman EL. Vascular endothelial growth factor prevents G93A-SOD1-induced motor neuron degeneration. Dev Neurobiol. 2009;69:871-84.

182. Murphy M, Dutton R, Koblar S, Cheema S, Bartlett P. Cytokines which signal through the LIF receptor and their actions in the nervous system. Prog Neurobiol. 1997;52:355-78.

183. Pierce RC, Bari AA. The role of neurotrophic factors in psychostimulant-induced behavioral and neuronal plasticity. Rev Neurosci. 2001;12:95-110.

184. Saarma M, Sariola H. Other neurotrophic factors: glial cell linederived neurotrophic factor (GDNF). Microsc Res Tech. 1999;45:292-302.

185. Schulte-Herbrüggen $\mathrm{O}$, Braun A, Rochlitzer S, Jockers-Scherübl MC, Hellweg R. Neurotrophic factors - a tool for therapeutic strategies in neurological. neuropsychiatric and neuroimmunological diseases? Curr Med Chem. 2007;14:2318-29.

186. Sendtner M, Carroll P, Holtmann B, Hughes RA, Thoenen H. Ciliary neurotrophic factor. J Neurobiol. 1994;25:1436-53. 